العلاقة بين الإرشاد الزراعى والمنظمات الريفية الزراعية بمحافظة كفر الشيخ كما يراها العاملون الإرشاديون حسين على هجرس، علام محمد طنطاوى'

ع - تمثلت أهم المعوقات التى تحد من فعالية العلاقــة بــين الإرشـــاد

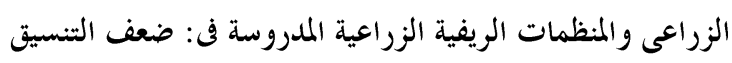

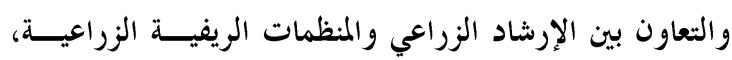

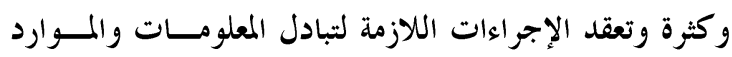

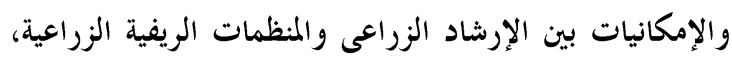

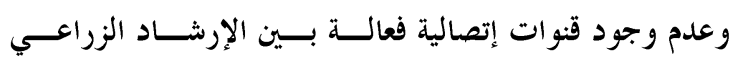

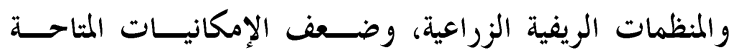
للإرشاد الزراعى والمنظمات الريفية بصفة عامة. ه- تمثلت أهم مقترحات المبحوثين لزيادة فعالية العلاقة بين الإرشاد

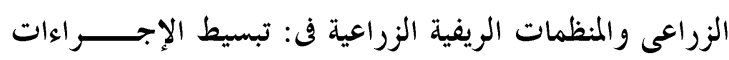

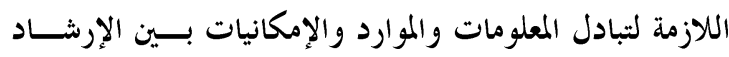

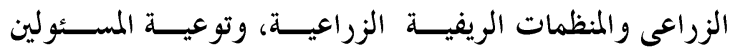

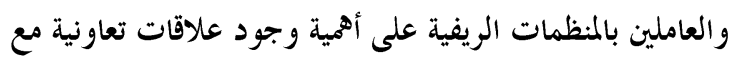
الإرشاد الزراعى، وتشجيع العـاملين بالمنظمــات الزراعيــة

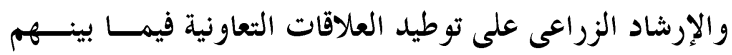

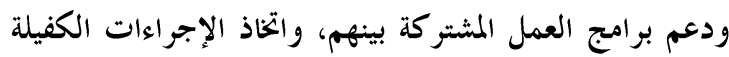

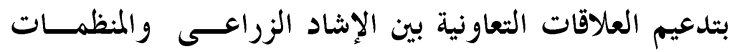

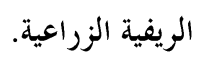

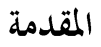

بعد عدة عقود من انشغال الباحثين والعلماء بقضايا التنمية الريفية، أصبح هناك شبه اتفاق بينهم على أهمية المنظمات الريفية

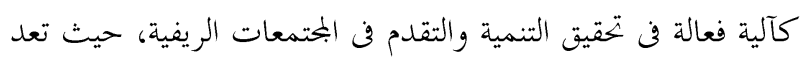
هذه المنظمات بمثابة الأدوات ومحاور الإرتكاز الرئيسية لأى جهد فيد

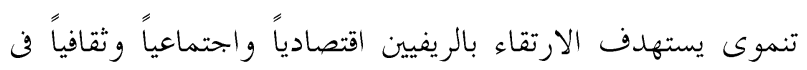

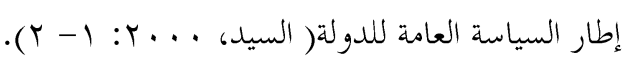

وقد تعددت وتنوعت المنظمات الريفية بتعدد وتنوع بحالات

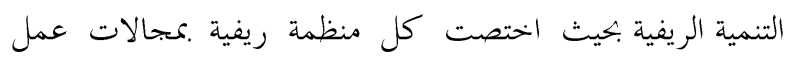

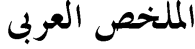

إستهدف البحث بصفة رئيسية التعرف على العلاقة بين الإرشاد

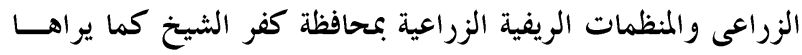
العاملون الإرشاديون، وذلك من خلال التعرف على طبيعة العلاقة بين

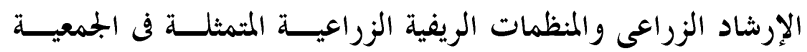

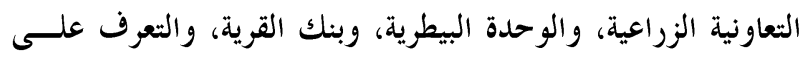
المعوقات التى تحد من وجود علاقات فعالة بين الإرشاد الزراعى وهذه ولنده المنظمات، و كذلك التعرف على مقترحات العاملين الإرشاديين لزيادة

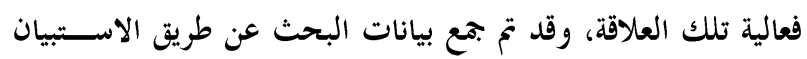

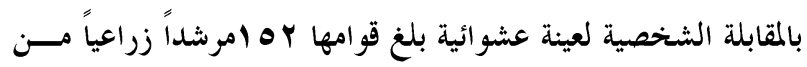

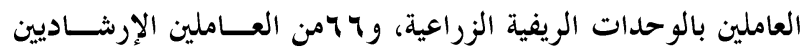

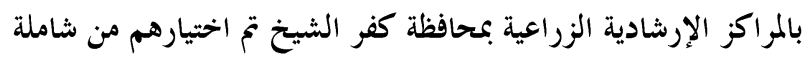

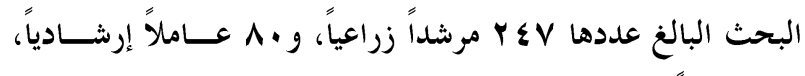

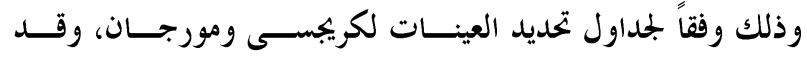

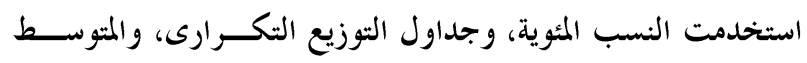

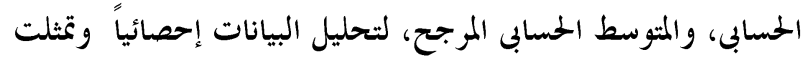

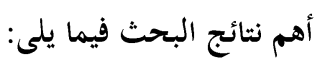
1 - أفاد أكثرمن ثلث المبحوثين عينتى البحث بضعف العلاقـة بــين

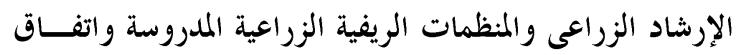

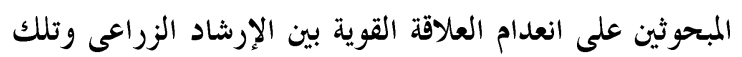

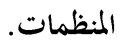
r- إحتلت الجمعية التعاونية الزراعية مكان الصدارة بالنسبة لقـــوة

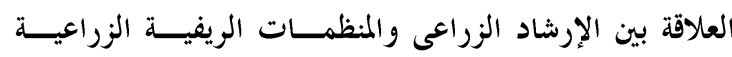

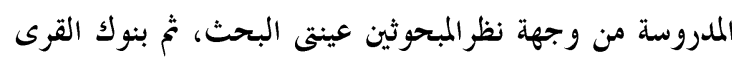

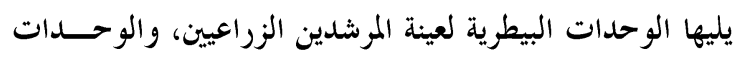
البيطرية ثم بنوك القرى لعينة مبحوثى المراكز الإرشادية. r- الشكل الرسمى هو السائد في معظم أبعاد علاقة الإرشاد الزراعى بالمنظمات الريفية الزراعية المدروسة. 
ويستخدم في قياس العلاقات التعاونية بين المنظمات أربعة أبعاد

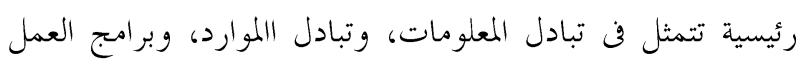

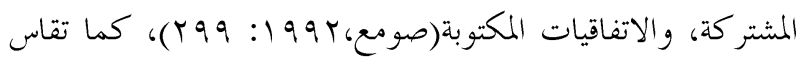

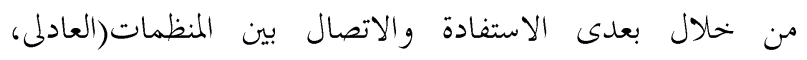

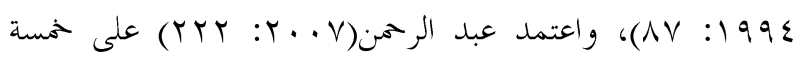

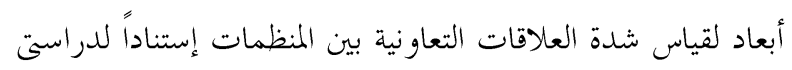

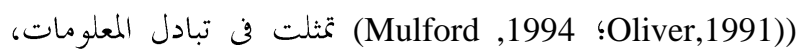
وتبادل الموارد، و برامج العمل المشتركة، وتداخل العضوية بين المنظمات، و والاتفاقيات الرسمية بين المنظمات. وعلى ضوء ذلك يمكن النظر إلى العلاقات التعاونية بين الإرشاد

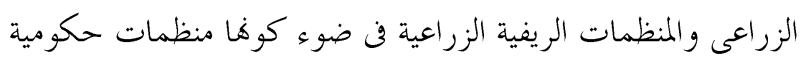

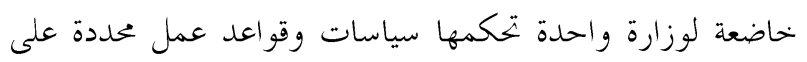

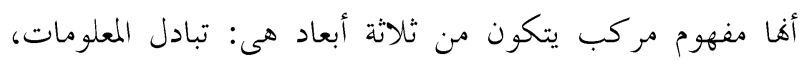
وتبادل الموارد، وبر امج العمل المشتر كة.

\section{المشكلة البحثية}

يستهدف العمل الإرشادى الزراعى كعمل ذو طبيعة تعليمية

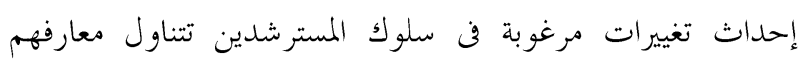
وتنمية مداركهم وكذا تحسين مهاراهم وقدراهم وتغيير إبتاهاهم كوسائل لتحقيق غايات أعمق وأشمل تنطوى على تحقيق الغايات

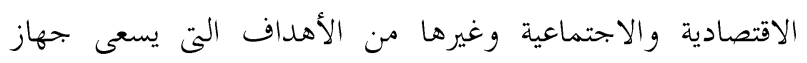

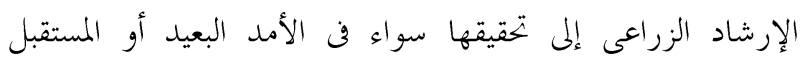

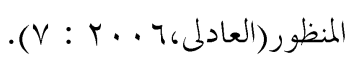

ويعمل الإرشاد الزراعى في تحقيق ذلك جنباً إلى جنب مع منظمات ومؤسسات وهيئات زراعية وغير زراعية يتصل عملها

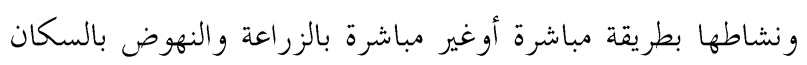

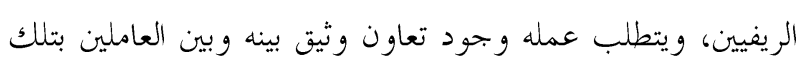

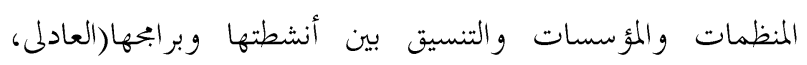
(9VT

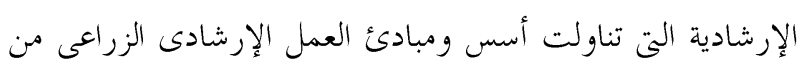

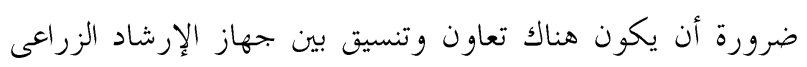

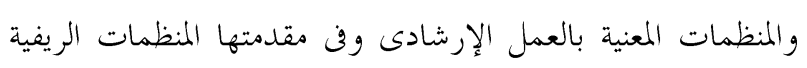

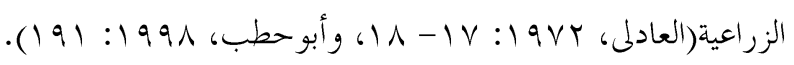

محددة. إلاّ أن هذه المنظمات تشترك جميعها في ثلاثة أمور أولها

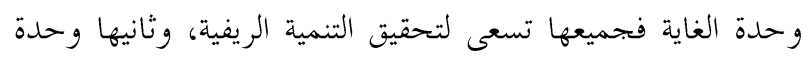

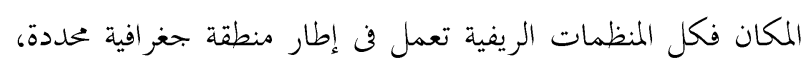

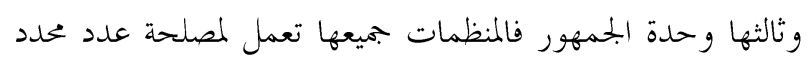
من السكان الريفيين الذين يقيمون في الوحدة المكانية والذين يتفاعلون مع تلك المنظمات في وقت واحد أو في أوقات مختلفة حسب الظروف( عبد اللا وصومع، 1990 (: . بـ) ويتطلب الأسلوب المتكامل في التنمية ضرورة التنسيق والتعاون والترابط بين الجهود المبذولة من المنظمات المختلفة وصهرها في بوتقة

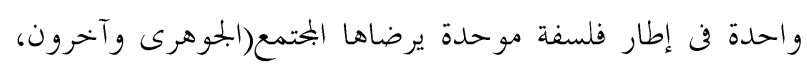

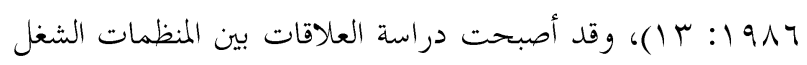

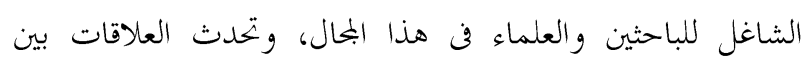

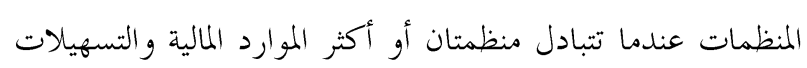

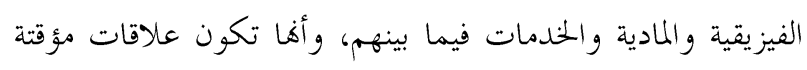

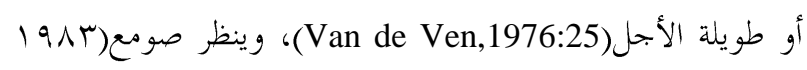

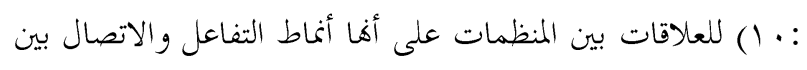

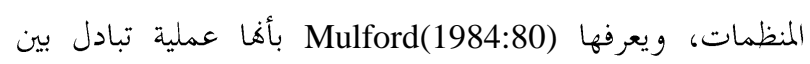
المنظمات، ويعرف التبادل المنظمى بأنه أى نشاط بين منظمتين يرمى ونى

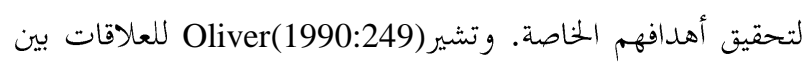

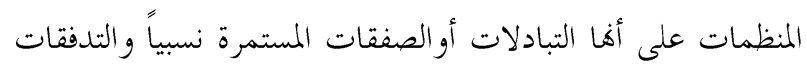
والروابط التى تحدث بين منظمة ومنظمة أخرى في بيئتها.

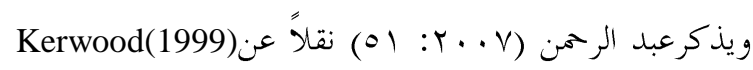

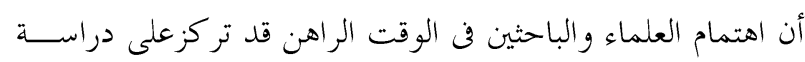

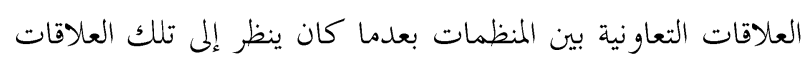
على أها علاقات تنافسية أو عدائية. وهدف العلاقات التعاونية بين المنظمات إلى توحيد الجهودة،

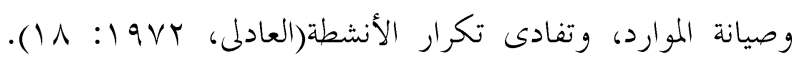

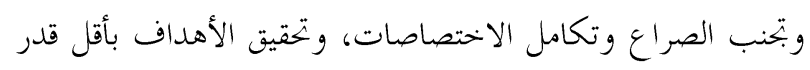

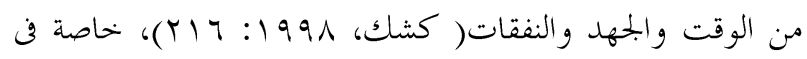

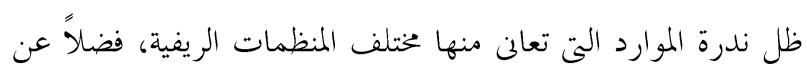

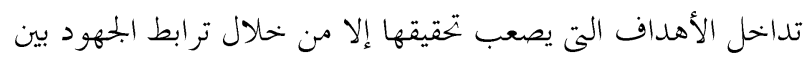

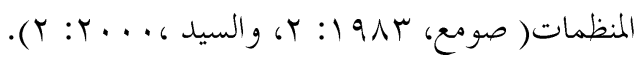


r- التعرف على المعوقات التي تحد من وجود علاقات فعالة بــين

الإرشاد الزراعى والمنظمات الريفية الزراعية المدروسة.

r- التعرف على مقتر حات العاملين الإرشاديين لزيادة فعالية العلاقة

بين الإرشاد الزراعى و المنظمات الريفية الزراعية المدروسة.

\section{الطريقـــة البحـــية}

أولاً: الجال الجفر افى والبشرى للبحث:

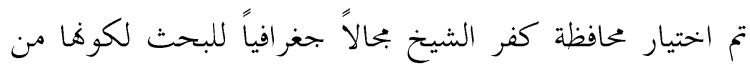

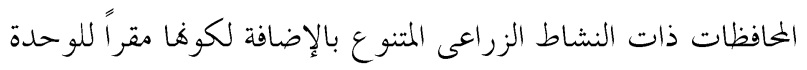

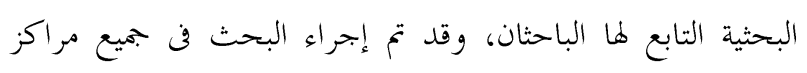

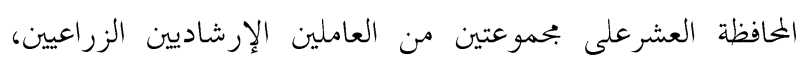

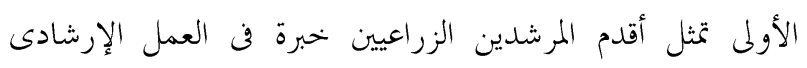

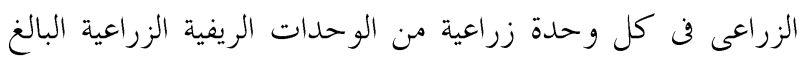

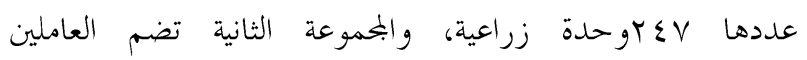
الإرشاديين بالمراكز الإرشادية الزراعية والبالغ عددهم . ، م عاملاً

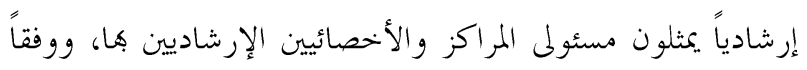
لجداول(Krejcie \&Morgan,1970:24)، بلغ حجم عينة المرشدين

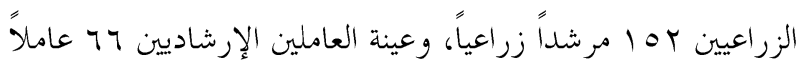
إرشادياً.

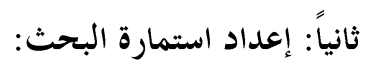

سبق إعداد إستمارة البحث القيام بدراسة إستكشافية للتعرف

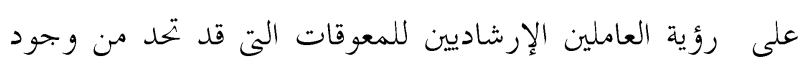
علاقات تعاونية فعالة بين الإرشاد الزراعى والمنظمات الريفية الريفية

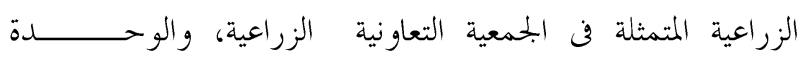

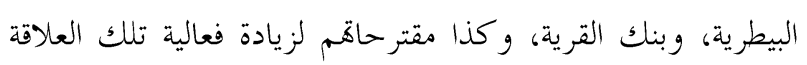

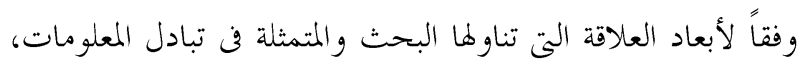

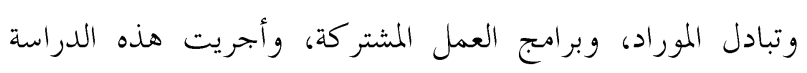

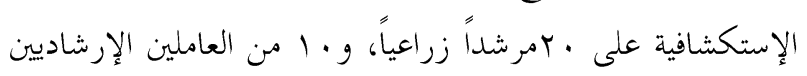

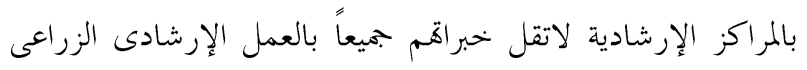

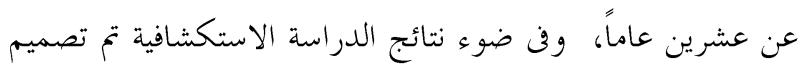

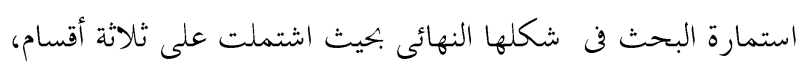

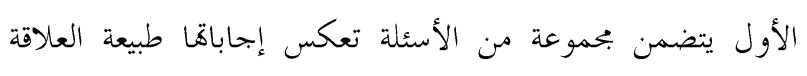

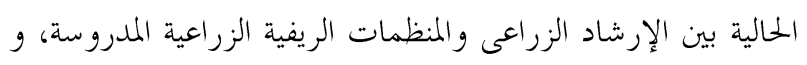

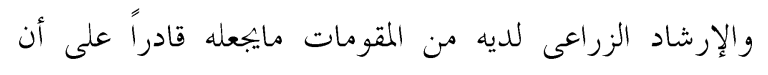
يعمل مع مختلف المنظمات الريفية خاصة المنظمات الريفية الزراعية

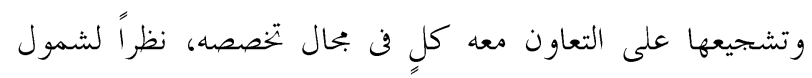
عمله معظم الأنشطة الإنتاجية الريفية التى هى محور الهتمام العديد من المنظمات الريفية، كما تصل خدماته لمعظم الفئات العمرية للريفيين من رجال وشباب ومرأة ريفية. وقد تيبن من استعر اض الدراسات الارشادية التئ أمكن للباحثين

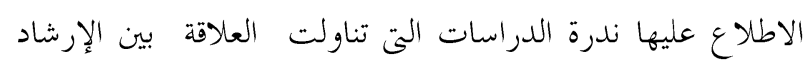

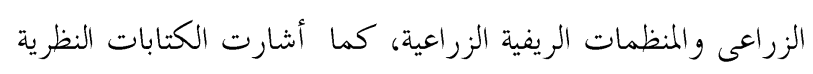

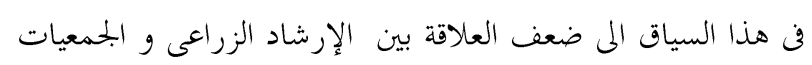

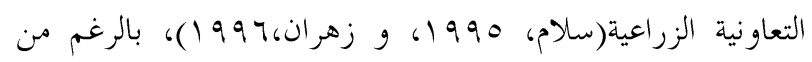

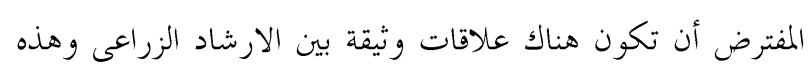

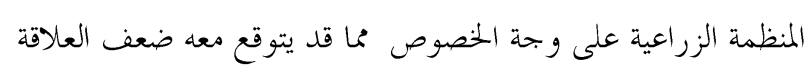
بين الارشاد الزراعى وباقى المنظمات الريفية الزراعية الأخرى

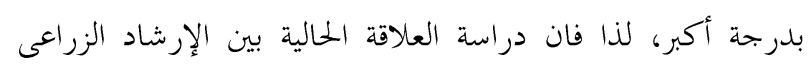

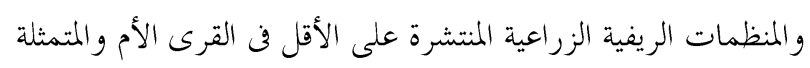

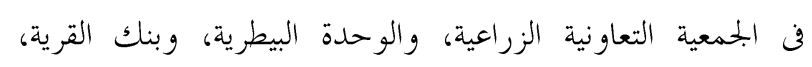

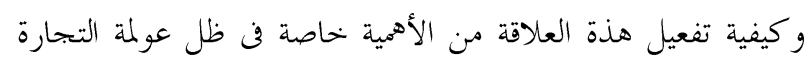

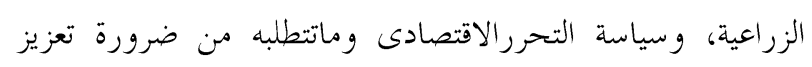

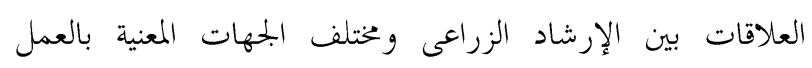

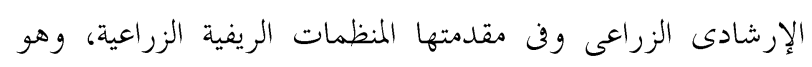

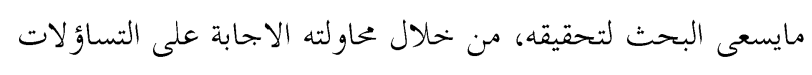

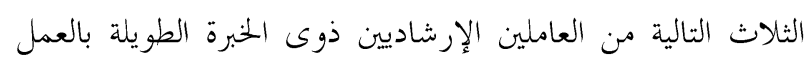

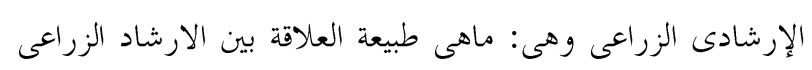

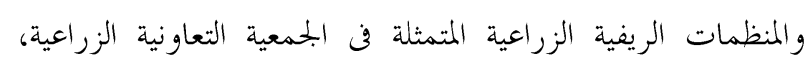

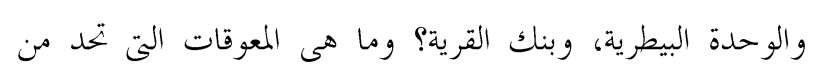

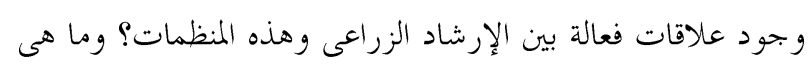

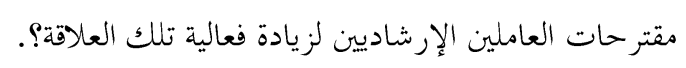

\section{أهداف البحث}

1 - التعرف على طبيعة العلاقة بين الإرشاد الزراعـى والمنظمــات

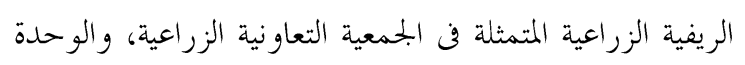

$$
\text { البيطرية، وبنك القرية. }
$$




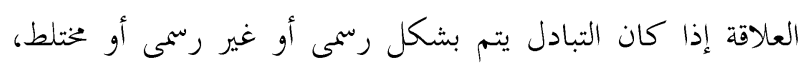

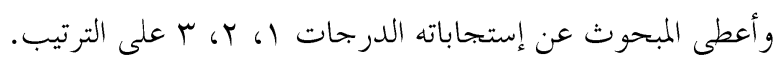
r- تبادل الموارد: يقصد بها في هذا البحث مدى لجوء الإرشاد

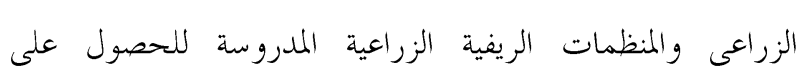

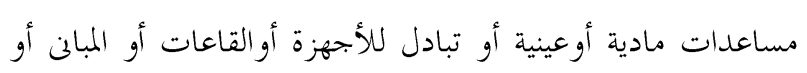

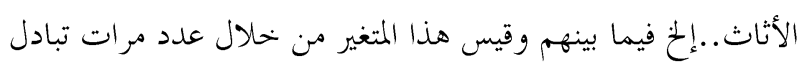

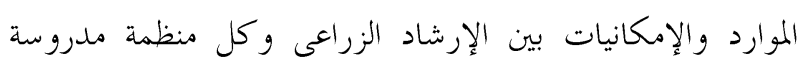

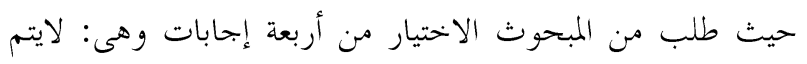

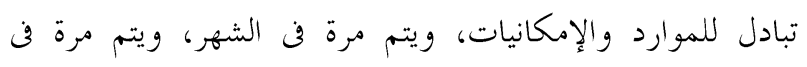
الأسبوع، ويتم مرة أو أكثرفى اليوم، وأعطى المبحوث عن إستجاباته فياته

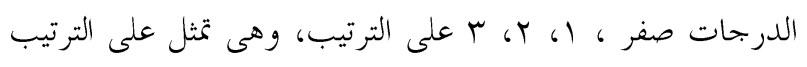

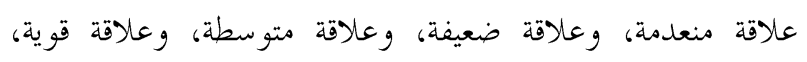

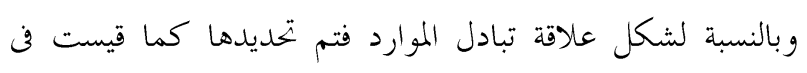
تبادل المعلومات. r- بر امج العمل المثتر كة: ويقصد هيا في هذا البحث مدى وجهود

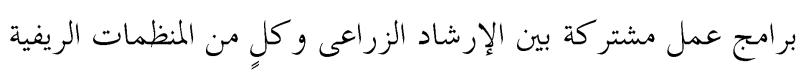

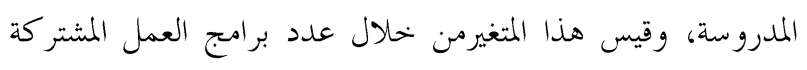

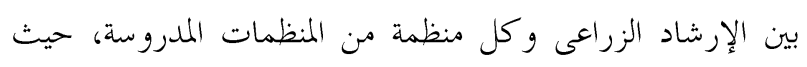

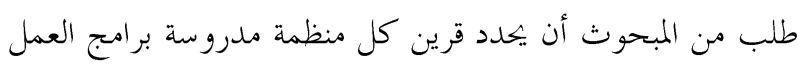
المشتر كة بين الإرشاد الزراعى وبينها، وتحددت قوة العلاقة كالآتى:

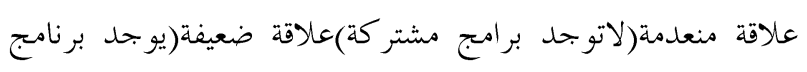
واحد)، علاقة متوسطة(يوجد برنابجين)، علاقة قوية(يوجد ثلاث

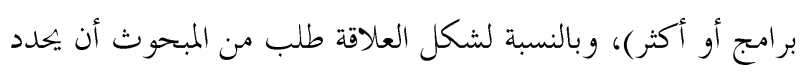
قرين كل برنامج عمل مشترك ذكره ما إذا كان هذا البرنامج يتم بشكل رسمى أو غير رسمى أو غختلط و أعطى المبحوث عن عن إستجاباته

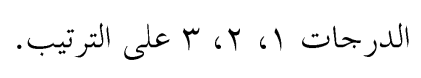

\section{(ب)المعوقات التى قد تحد من وجود علاقات فعالة بين الإرشاد}

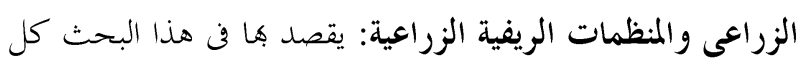

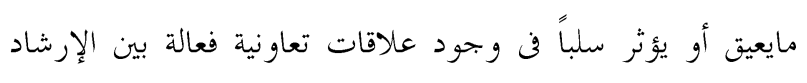

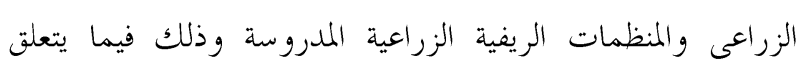

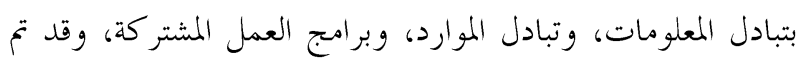

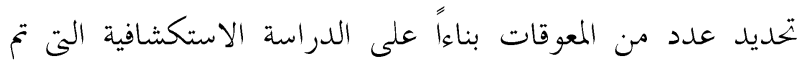

تناول القسم الثانى بحموعة من المعوقات التى قد تحد من وجود علاقات فعالة بين الإرشاد الزراعى والمنظمات الريفية الزراعية

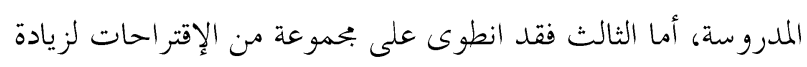

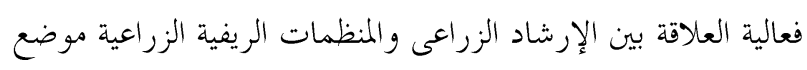

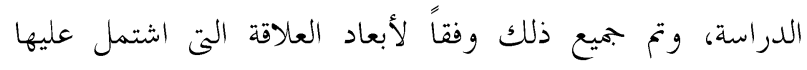
البحث.

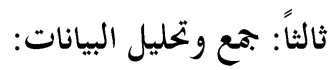
تم جمع البيانت البحثية خلال شهرى مايو ويونيو من عام لمان

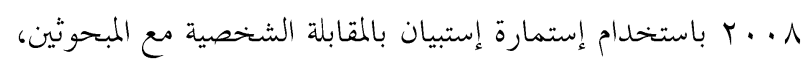

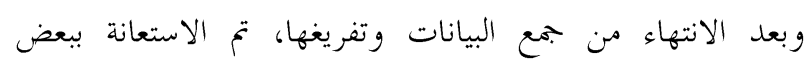
الأساليب الإحصائية التى تساعد في تحقيق أهداف البحث تمثلت في: ولنيات

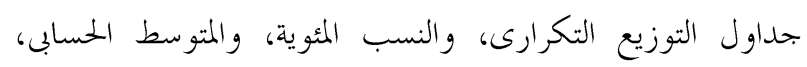
والمتوسط الحسابى المرجح. رابعاً: المتغيرات البحثية وقياسها: (أ)طبيعة العلاقة بين الإرشاد الزراعى والمنظمات الريفية الزراعية: يقصد ها فن هذا البحث ماهو كائن من علاقة تعاونية بين الإرشاد الزراعى والمنظمات الريفية الزراعية المتمثلة في الجمعية التعاونية

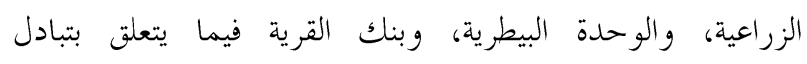

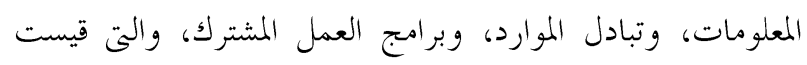
جميعها بمحورى قوة العلاقة وشكل العلاقة كما يلى: ا - تبادل المعلومات: ويقصد بها في هذا البحث مدى قيام الإرشاد الزراعى والمنظمات الريفية الزراعية المدروسة بتبادل الآراء والخبرات

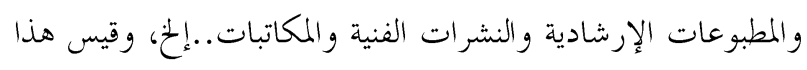

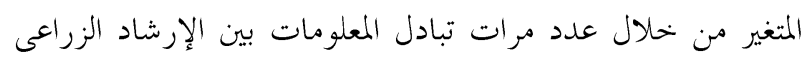

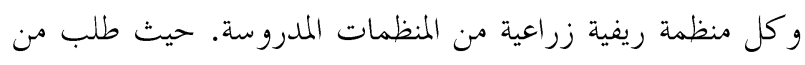

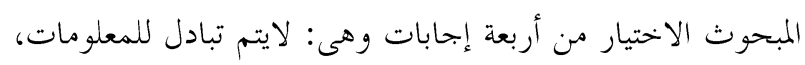

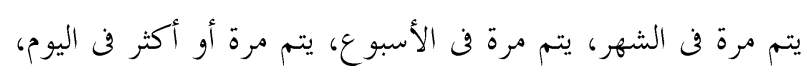

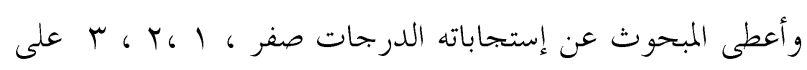

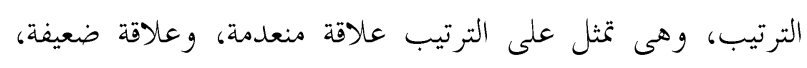

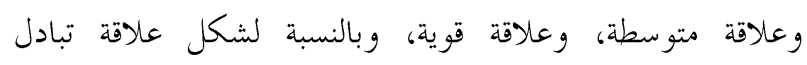
المعلومات فطلب من المبحوث أن يهدد قرين كل بعد من وعنة وأبعاد 


\section{ا- قوة العلاقة بين الإرشاد الزراعى والجمعيات التعاونيسـة}

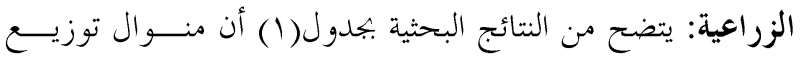
المبحوثين لقوة العلاقة بين الإرشاد الزراعى والجمعيــات التعاونيـــة

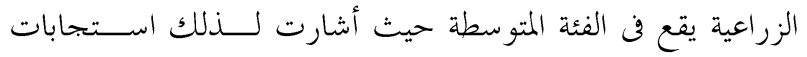

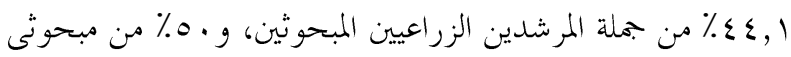

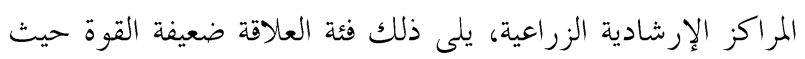

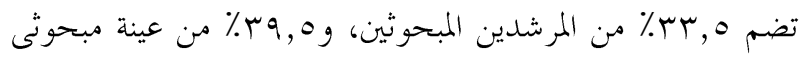

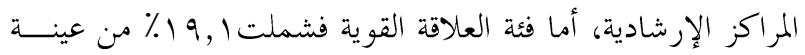

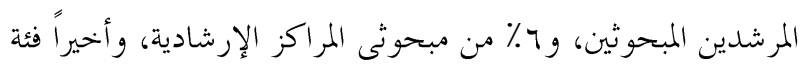

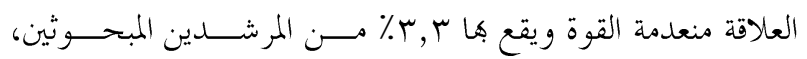

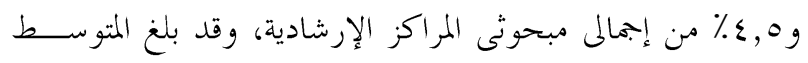

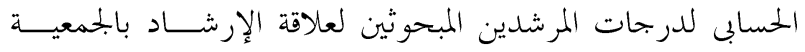
التعاونية ؟, عدرجة، ولمبحوثى المراكز الإرشادية م, بدرجة، ويتضح

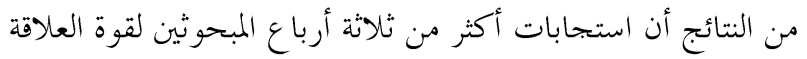

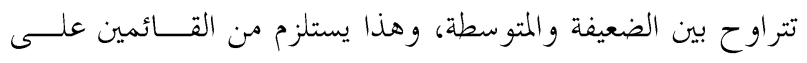

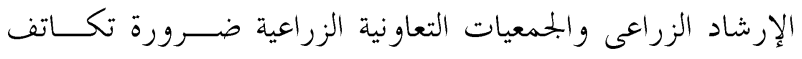

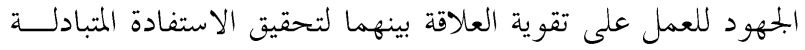

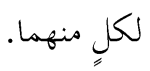

وفيما يتعلق بأبعاد العلاقة بين الإرشاد الزراعى والجمعية

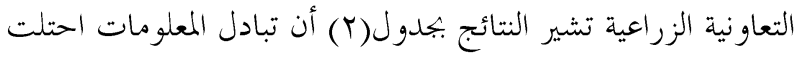

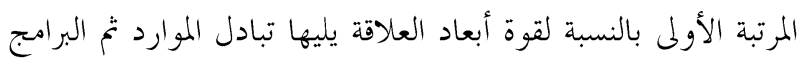

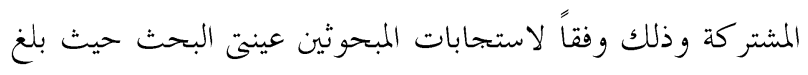

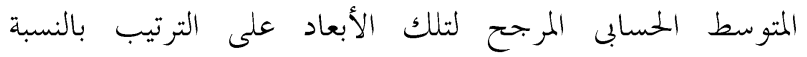

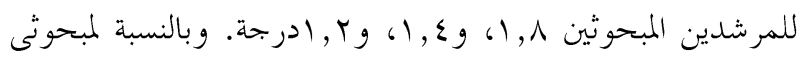

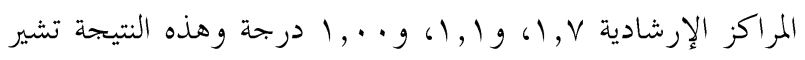

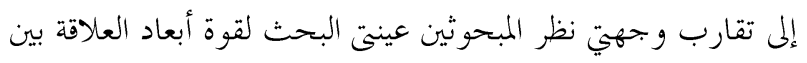
الإرشاد الزراعى والمجمعية التعاونية الزراعية.
إجراؤها قبل هذه الدراسة والتى في ضوء نتائجها تم وضع قائمة تضم 11 معوقات لبرامج العمل المشتر كة، وطلب من المبحوث أن يختار ماير اه لمعاه

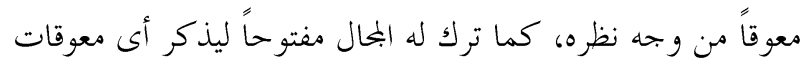
أخرى في كل بعد من الأبعاد الثلاثة. وقد أضاف المبحوثون في

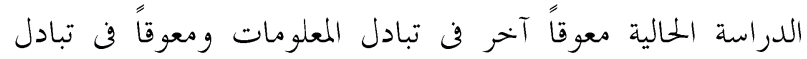

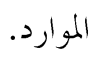

(جـ) مقترحات العاملين الإرشاديين لزيادة فعالية العلاقة بين

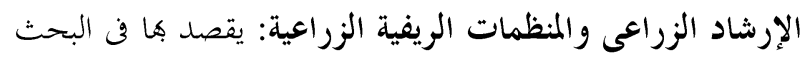

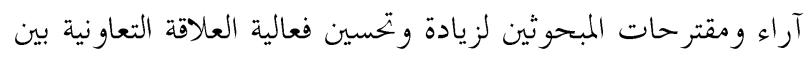
الإرشاد الزراعى والمنظمات الريفية الزراعية المدروسة وذلك فيما

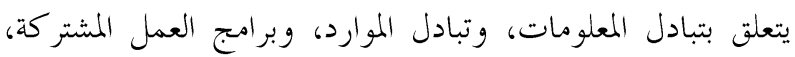
وقد تم تحديد عدد من المقترحات بناءاً على الدراسة الاستكشافية التى تم إجراؤها قبل هذه الدراسة والتئ في ضوء نتائجها تم وضع

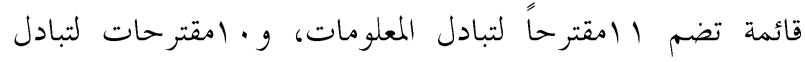

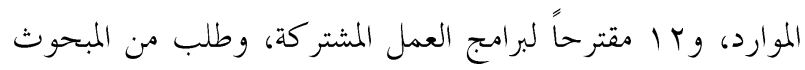

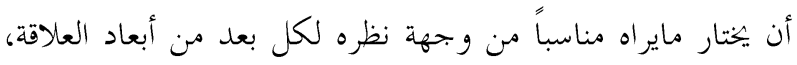

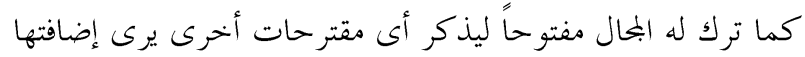

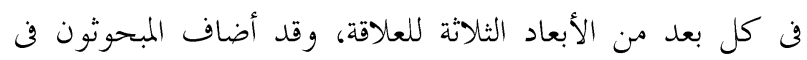

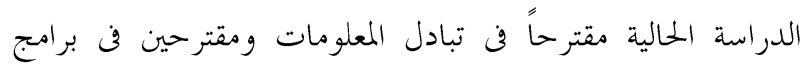

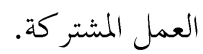

\section{النتائج ومناقشتها}

أمكن التعرف على طبيعة العلاقــة بــين الإرشـــاد الزراعـى والمنظمات الريفية الزراعية على النحو التالى:

(أ)طبيعة العلاقة بين الإرشاد الزراعـى والجمعيــات التعاونيـــة الزراعية:

جدول ا ـ التوزيع العددى والنسبى لقوة العلاقة بين الإرشاد الزراعى والجمعية التعاونية الزراعية

\begin{tabular}{|c|c|c|c|c|}
\hline \multicolumn{2}{|c|}{ العاملون الإرشاديون بالمراكز الإرشادية } & \multicolumn{2}{|c|}{ المرشدون الزراعيون على مستوى القرية } & \multirow{2}{*}{ الفئــــــــــات } \\
\hline$\%$ & 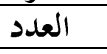 & $\%$ & 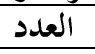 & \\
\hline$\varepsilon, 0$ & r & $r, r$ & 。 & منعدمـــة (صفر) \\
\hline$r 9,0$ & ד & $r \mu, 0$ & 01 & ضعيفة ( \\
\hline$\bullet \cdot$, & سז & $\varepsilon \varepsilon, 1$ & $7 \mathrm{~V}$ & متوسطة ( ع - -7) \\
\hline $7, \cdot$ & $\varepsilon$ & 19,1 & rq & قوية (a-V) \\
\hline $1 \ldots$ & 74 & $1 \ldots$ & $10 Y$ & الإجمالى \\
\hline
\end{tabular}


جدول Y. التوزيع العددى والنسبى لقوة أبعاد العلاقة بين الإرشاد الزراعي والجمعية التعاونية الزراعية

\begin{tabular}{|c|c|c|c|c|c|c|c|}
\hline \multicolumn{3}{|c|}{ العاملون الإرشاديون بالمراكز الإرشادية } & \multicolumn{3}{|c|}{ المرشدون الزراعيون على مستوى القرية } & \multirow{2}{*}{\multicolumn{2}{|c|}{ الفئــــــــــــــــات }} \\
\hline البر امج المشتر كة & تبادل الموارد & تبادل المعلومات & البر امج المشتر كة & تبادل الموارد & تبادل المعلومات & & \\
\hline TV & $r \mu$ & 1. & or & Tr & 10 & العدد & \\
\hline$\varepsilon \cdot, q$ & $r \varepsilon, \wedge$ & $10, r$ & $r \varepsilon, r$ & $Y 1,1$ & 9,9 & $\%$ & منعدمهل \\
\hline IV & $r 1$ & $r 1$ & rr & 7. & $\varepsilon V$ & العدد & \\
\hline$r_{0, \Lambda}$ & 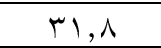 & $r, \Lambda$ & $r, 1$ & rq,o & $r \cdot, q$ & $\%$ & ضعيفd \\
\hline 10 & 17 & 17 & $\varepsilon V$ & س & 01 & 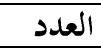 & b \\
\hline KY,V & $r \varepsilon, Y$ & $r \xi, Y$ & $r \cdot, q$ & $r,, V$ & rr, & $\%$ & متوسط \\
\hline V & 7 & 19 & YI & Tr & $r q$ & العدد & \\
\hline $1 \cdot, 7$ & 9,1 & $r \wedge, \wedge$ & $1 \mu, \Lambda$ & $10, r$ & Yo,V & $\%$ & هويه \\
\hline $1, \cdots$ & 1,1 & $1, v$ & $1, Y$ & $1, \varepsilon$ & 1,1 & المرجح & المتوسط ا. \\
\hline
\end{tabular}

(ب)(طبيعة العلاقة بين الإرشاد الزراعى والوحدات البيطرية: ا- قوة العلاقة بين الارشاد الزراعى والوحدات البيطرية: يتضح من النتائج البحثية بجدول(r) أن منوال توزيع المبحوثين

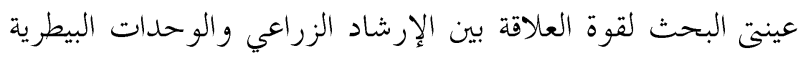

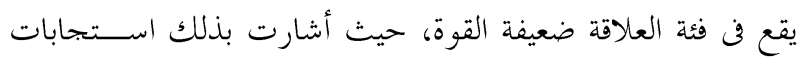

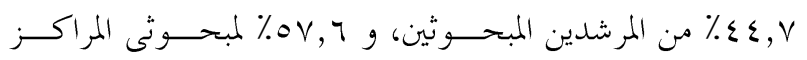

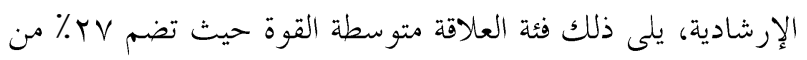

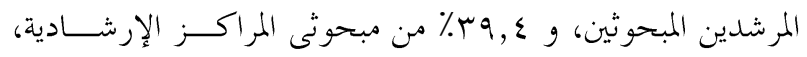

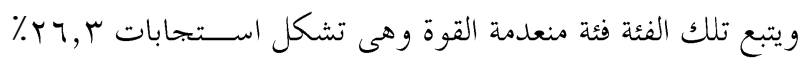

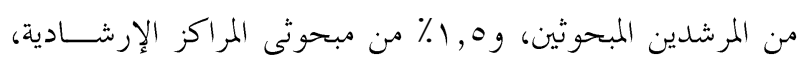

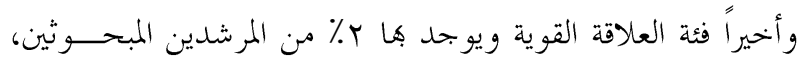

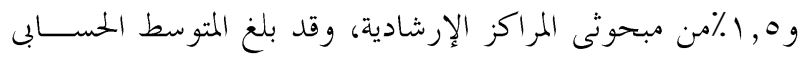

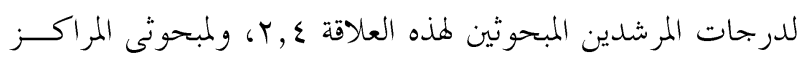
الإرشادية r, ب درجة. وتشير هذه النتائج بصفة عامة إلى ضعف العلاقة بين الإرشاد

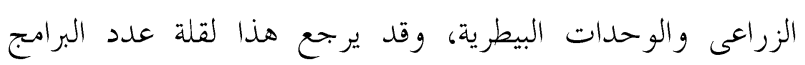

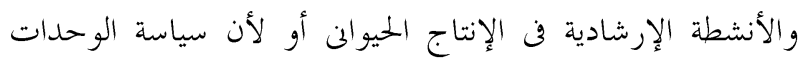

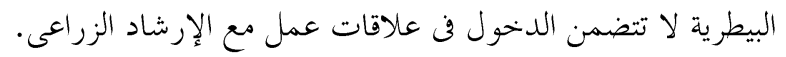

r- شكل العلاقة بين الإرشاد الزراعى والجمعيات التعاونية

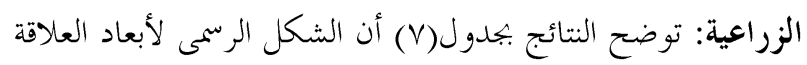

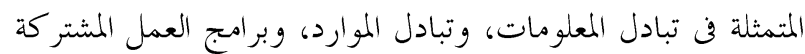

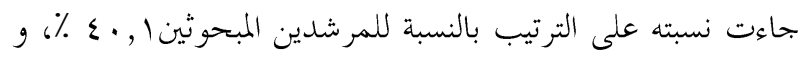

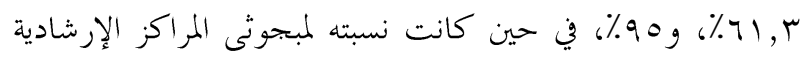

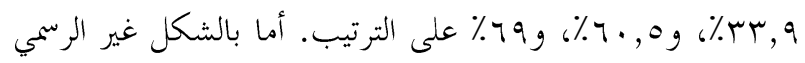

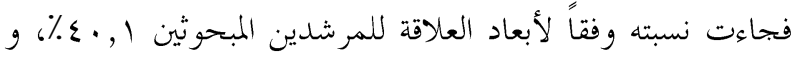

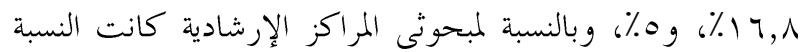

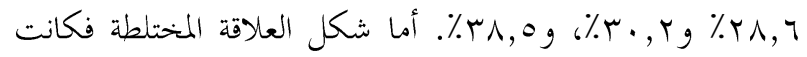

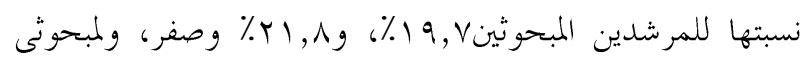

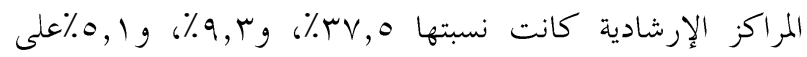
الترتيب وفقاً لأبعاد العلاقة. ويتضح من هذه النتائج سيادة الشكل الرسمى للعلاقة بين الإرشاد الزراعي والجمعيات التعاونية الزراعية في بعدى تبادل

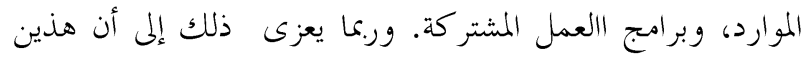

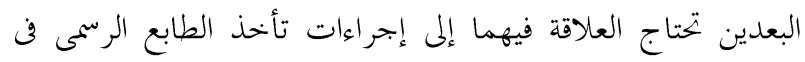

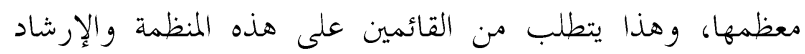
الزراعي أن تكون هناك اتفاقيات رسمية تنظم عمليت تبادل الموارد، و برامج العمل المشتر كة فيما بينهم.

جدول م. التوزيع العددى والنسبى لقوة العلاقة بين الإرشاد الزراعى والوحدات البيطرية

\begin{tabular}{|c|c|c|c|c|}
\hline \multicolumn{2}{|c|}{ العاملون الإرشاديون بالمراكز الإرشادية } & \multicolumn{2}{|c|}{ المر شدون الزراعيون على مستوى القرية } & \multirow{2}{*}{ الفئـــــــــــات } \\
\hline$\%$ & 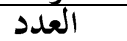 & $\%$ & العدد المد & \\
\hline 1,0 & 1 & rY,r & $\varepsilon$. & منعدمــة \\
\hline$\circ V, T$ & rᄉ & $\varepsilon \varepsilon, V$ & 71 & ضعيفة ( \\
\hline$r_{q, \xi}$ & rT & rV, & $\leqslant 1$ & متوسطة ( ع - - ) \\
\hline 1,0 & 1 & $r$, & r & قو يسـة ( \\
\hline $1 \ldots$ & 77 & $1 \ldots$ & 104 & الإجمالي \\
\hline
\end{tabular}




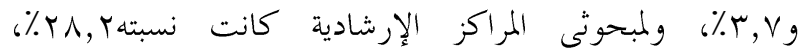

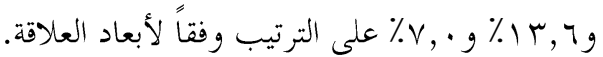

ويتضح من هذه النتائج ان الشكل الرسمى للعلاقات التعاونية

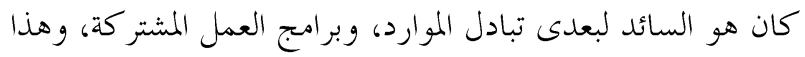
يشير إلى أن وجود القواعد الرسمية المنظمة للتعاون بين المنظمات المختلفة يعد الاساس لوجود العلاقات بين المنظمات الريفية الزراعية

$$
\text { و الإرشاد الزراعي. }
$$

\section{(جـ)طبيعة العلاقة بين الإرشاد الزراعى وبنولك القرى:}

أوضحت النتائج البحثية بجدول(0) أن منوال توزيع المبحوثين

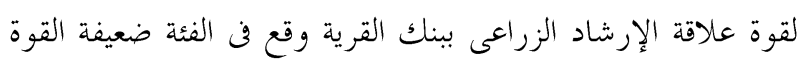

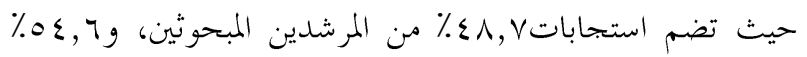

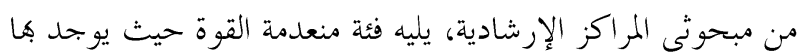

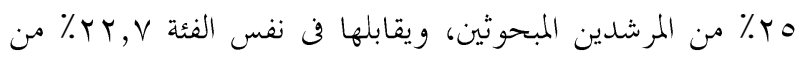
مبحوثى المراكز الإرشادية، في حين يقع في فئة متوسطة القوة

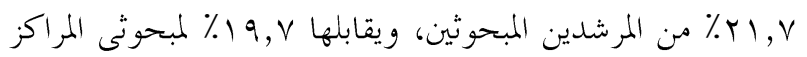

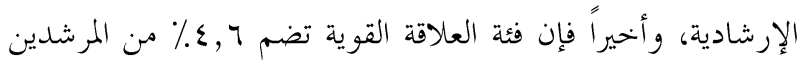

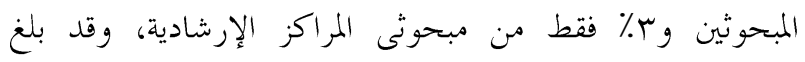

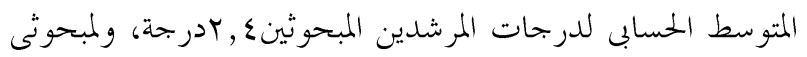
المراكز الإرشادية r, ب درجة.

يتضح مما سبق أن منوال توزيع المبحوثين يقع في فئة العلاقة

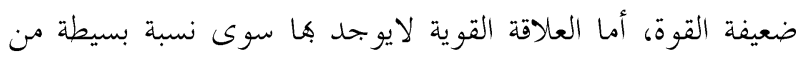

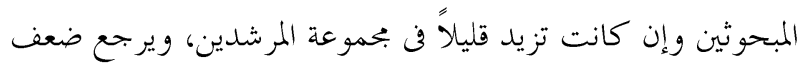

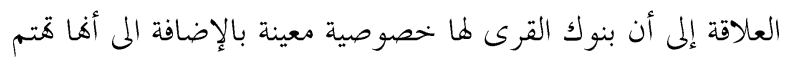

جدول \& ـ التوزيع العددى والنسبى لقوة أبعاد العلاقة بين الإرشاد الزراعى والوحدات البيطرية

\begin{tabular}{|c|c|c|c|c|c|c|c|}
\hline \multicolumn{3}{|c|}{ العاملون الإرشاديون بالم اكز الارشادية } & \multicolumn{3}{|c|}{ المرشدون الزراعيون على مستوى القرية } & \multirow{2}{*}{\multicolumn{2}{|c|}{ الفئــــــــــات }} \\
\hline البر امج المشتر كة & تبادل الموارد & تبادل المعلومات & البر امج المشتر كة & تبادل الموارد & تبادل المعلومات & & \\
\hline r & TY & 9 & VI & $V V$ & 10 & العدد & منعلمة \\
\hline$r \varepsilon, \wedge$ & س & $1 \pi, 7$ & $\varepsilon V, V$ & $0 ., \mathrm{V}$ & 00,9 & $\%$ & منعدمه \\
\hline ro & TV & rT & $\leqslant 1$ & $r v$ & $\varepsilon r$ & العدد & ضعـف \\
\hline$r v, q$ & $\varepsilon \cdot, q$ & $\varepsilon \wedge, 0$ & $r V,$. & $r \varepsilon, r$ & $r \wedge, r$ & $\%$ & صفيع \\
\hline 10 & $1 \pi$ & YY & rᄉ & YY & $\begin{aligned} 1 \\
\end{aligned}$ & العدد & ه \\
\hline$T Y, V$ & $19, \mathrm{~V}$ & r r & $1 \wedge, \varepsilon$ & $1 \varepsilon, 0$ & $1 r, \Lambda$ & $\%$ & متر \\
\hline$r$ & $\varepsilon$ & $r$ & YI & 17 & $r$ & العدد & \\
\hline$\varepsilon, 0$ & 7,1 & $\varepsilon, 0$ & $v, q$ & $1 ., 0$ & $r, \cdot$ & $\%$ & d \\
\hline$\cdot, 9 \mathrm{~V}$ & $\cdot, 9 \wedge$ & $1, r$ & $1, \ldots$ & $\cdot, \wedge$ & $\cdot, 7$ & 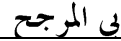 & 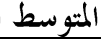 \\
\hline
\end{tabular}

وفيما يتعلق بأبعاد العلاقة بين الإرشاد الزراعى والوحدات

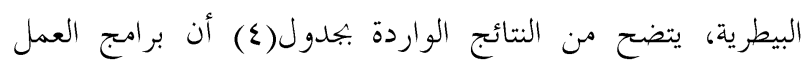

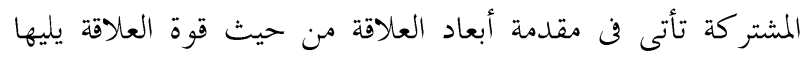
تبادل الموارد ثم تبادل المعلومات حيث بلغ المتوسط الحسابى المرجح

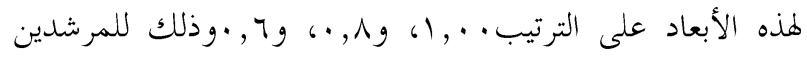

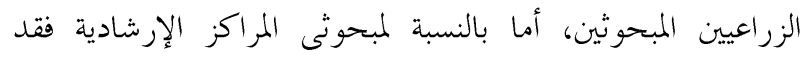

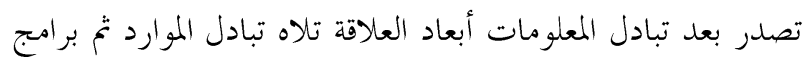

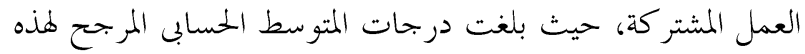

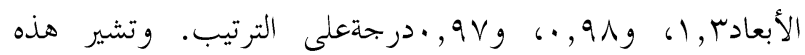

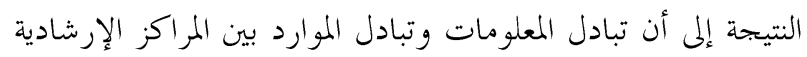

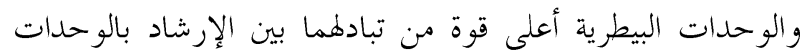
الزراعية والوحدات البيطرية.

\section{Y- شكل العلاقة بين الإرشاد الزراعى والوحدات البيطرية:} توضح النتائج بجدول(V) أن الشكل الرسمى لأبعاد العلاقة

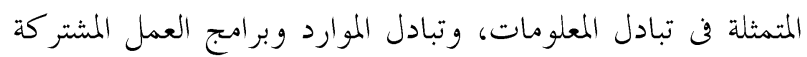

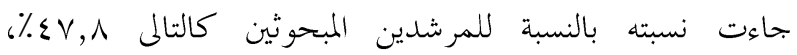

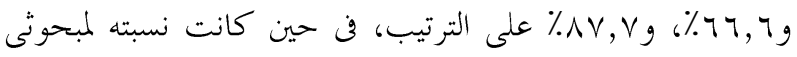

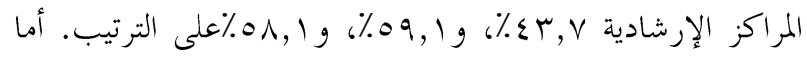

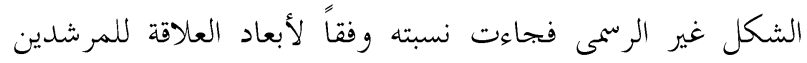

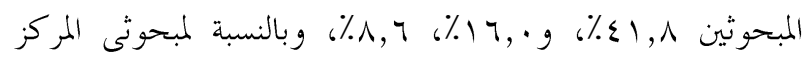

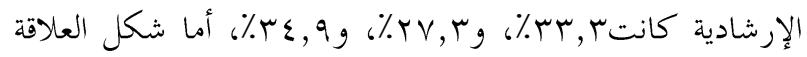

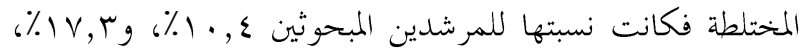


جدوله ـ. التوزيع العددى والنسبى لقوة العلاقة بين الإرشاد الزراعى وبنوك القرى

\begin{tabular}{|c|c|c|c|c|}
\hline \multicolumn{2}{|c|}{ العاملون الإرشاديون بالمراكز الإرشادية } & \multicolumn{2}{|c|}{ المرشدون الزراعيون على مستوى القرية } & \multirow{2}{*}{ الفئـــــــات } \\
\hline$\%$ & 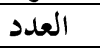 & $\%$ & 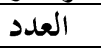 & \\
\hline rr,V & 10 & ro,... & $\mu_{\Lambda}$ & منعدمــة (صفر ) \\
\hline $0 \leqslant, 4$ & 4r & $\varepsilon \wedge, \vee$ & $V \varepsilon$ & ضعيفة (1- \\
\hline $19, \mathrm{~V}$ & r & 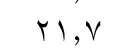 & זr & متوسطة ( ؟ - ؟) \\
\hline$r,$. & r & $\varepsilon, 7$ & $\mathrm{v}$ & قوية ( \\
\hline $1 \ldots$ & 4 & $1 \ldots$ & $10 \mathrm{r}$ & الإممالي \\
\hline
\end{tabular}

العلاقة المتمثلة في تبادل المعلومات، وتبادل الموارد، وبرامج العمل

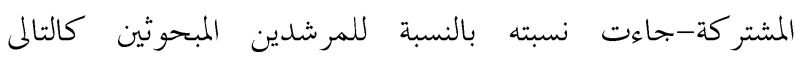

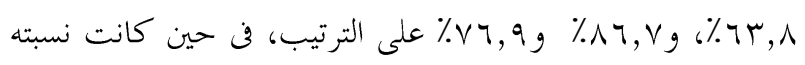

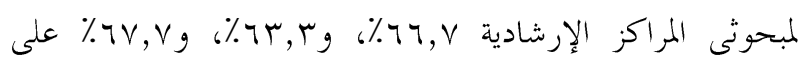

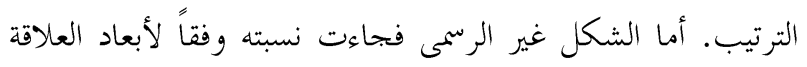

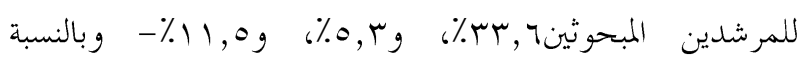

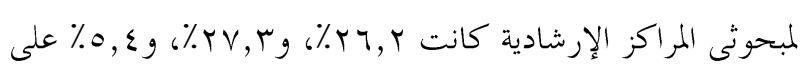

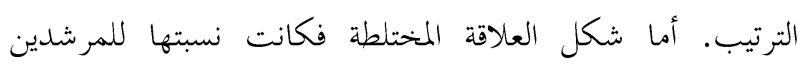

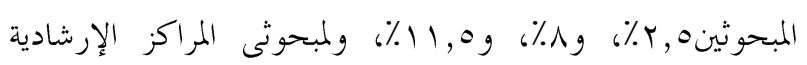

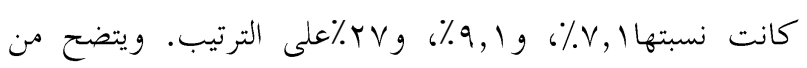

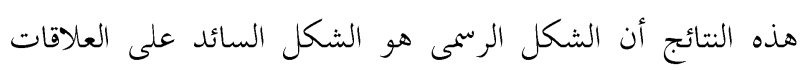

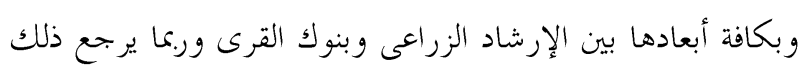
كللطبيعة الخاصة لعمل بنوك القرى.

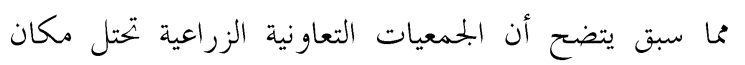

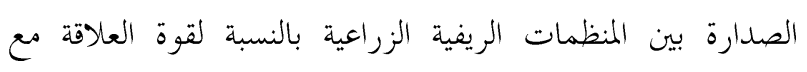

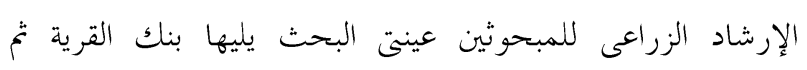

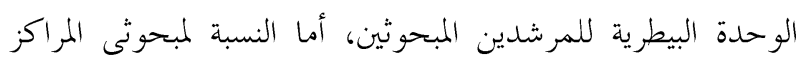
فتلى الجمعيات التعاونية الزراعية الوحدة البيطرية ثم بنك القرية.
في المقام الأول لتحقيق الربح أما الإرشاد الزراعى فهو خدمة بحانية للزراع. وفيما يتعلق بأبعاد العلاقة بين الإرشاد الزراعى وبنوك القرى،

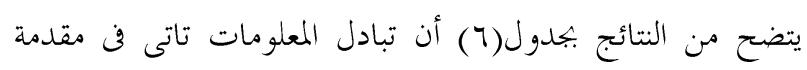

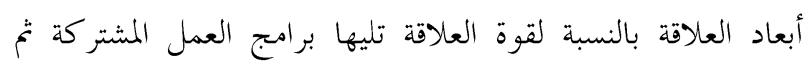

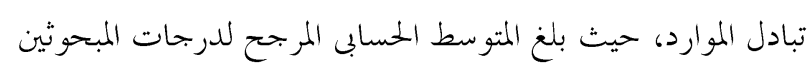

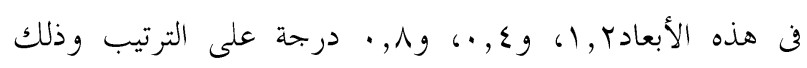

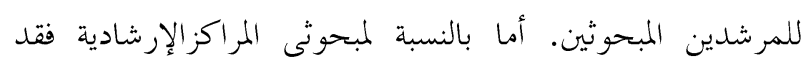

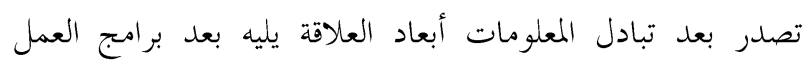

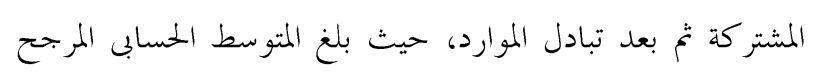

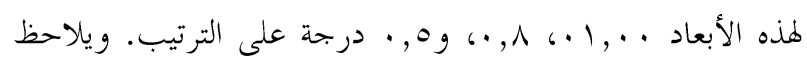

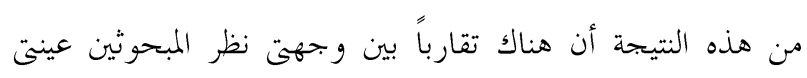

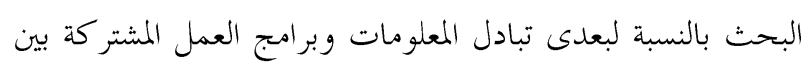

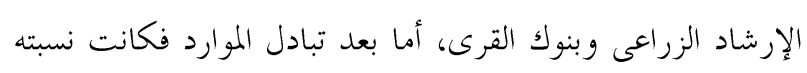
أعلى للمرشدين المبحوثين من مبحوثى المراكز الإرشادية. r- شكل العلاقة بين الإرشاد الزراعى وبنوك القرى:

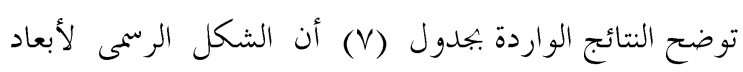

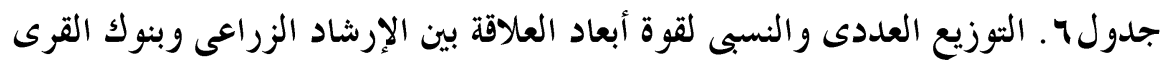

\begin{tabular}{|c|c|c|c|c|c|c|c|}
\hline \multicolumn{3}{|c|}{ العاملون الإرشاديون بالمراكز الإرشادية } & \multicolumn{3}{|c|}{ المرشدون الزراعيون على مستوى القرية } & & \multirow{2}{*}{ لفئـــــــــات } \\
\hline البر امج المشتر كة & تبادل الموارد & تبادل المعلومات & البرامج المشتر كة & تبادل الموارد & تبادل المعلومات & & \\
\hline$r q$ & $\varepsilon \varepsilon$ & YY & $\Lambda \varepsilon$ & $11 \mathrm{~V}$ & $r \Lambda$ & العلد العد ا & \\
\hline$\varepsilon r, q$ & $7 \pi, \mathrm{V}$ & rr, r & $00, r$ & VV, & $1 \Lambda, \varepsilon$ & $\%$ & منعدمه \\
\hline ro & 14 & ro & ז & 10 & $\mathrm{~V} 4$ & العدد & \\
\hline$r v, q$ & $19, \mathrm{~V}$ & $r v, \Lambda$ & $r T, V$ & 9,9 & 0. & $\%$ & ضعيفه \\
\hline 11 & 9 & 10 & 17 & 17 & $\sum r$ & العدد & مت سمطة \\
\hline $17, \mathrm{~V}$ & $1 \%, 4$ & $r \varepsilon, V$ & $1 ., 0$ & 1,0 & $r V, T$ & $\%$ & متوسطه \\
\hline 1 & 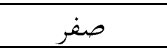 & $\varepsilon$ & 17 & $\varepsilon$ & 7 & العدد & ق \\
\hline 1,0 & صفر & 7,1 & $1 \cdot, 0$ & $r, T$ & $r, q$ & $\%$ & لوية \\
\hline$\cdot, \Lambda$ &., 0 & $1, \ldots$ & $\cdot, \Lambda$ & $\cdot, \varepsilon$ & $1, r$ & المرجح & 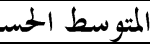 \\
\hline
\end{tabular}




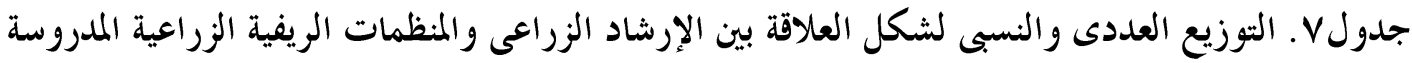

\begin{tabular}{|c|c|c|c|c|c|c|c|c|}
\hline \multicolumn{3}{|c|}{ العاملون الإرشاديون بالم اكز الإرشادية } & \multicolumn{3}{|c|}{ المرشدون الزراعيون على مستوى القرية } & \multirow{2}{*}{\multicolumn{2}{|c|}{ شكل العلاقــــــة }} & \multirow{2}{*}{ البعاد العلاقة } \\
\hline بنك القرية & البيطرية & التجاونية & بنك القرية & البيطرية & التجاونية & & & \\
\hline$r A$ & ro & 19 & $V_{4}$ & $r T$ & 00 & العدد & \multirow{2}{*}{ رسمى } & \multirow{6}{*}{ المعلومات } \\
\hline $7 \pi, V$ & $\varepsilon r, q$ & $r r, q$ & $\pi r, \Lambda$ & $\varepsilon \vee, \Lambda$ & $\varepsilon \cdot, 1$ & $\%$ & & \\
\hline 11 & 19 & 17 & $\varepsilon$. & rA & 00 & العدد & \multirow[b]{2}{*}{ غير رسمى } & \\
\hline$r Y, Y$ & $r \mu, r$ & $r \Lambda, T$ & rr, & $\xi 1, \Lambda$ & $\varepsilon \cdot, 1$ & $\%$ & & \\
\hline$r$ & $\pi$ & $r 1$ & $r$ & $v$ & TV & العدد & \multirow{2}{*}{ مختلط } & \\
\hline$v, 1$ & $r \Lambda, r$ & $r v, 0$ & $r, 0$ & $1 \cdot, \varepsilon$ & $19, \mathrm{~V}$ & $\%$ & & \\
\hline $1 \varepsilon$ & ry & $r 4$ & 70 & o. & $V T$ & العدد & \multirow{2}{*}{ رسمى } & \multirow{6}{*}{ 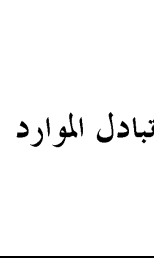 } \\
\hline$\pi r, T$ & 09,1 & $7 ., 0$ & $\Delta T, V$ & $7 \pi, 4$ & $T 1, r$ & $\%$ & & \\
\hline 7 & IT & ir & $\varepsilon$ & IT & $r$. & العدد & & \\
\hline$r V, r$ & $r V, r$ & $r \cdot, r$ & $0, r$ & 17, & $17, \wedge$ & $\%$ & عير رسىى & \\
\hline$r$ & 7 & $\varepsilon$ & 7 & $1 \pi$ & $T_{T}$ & العدد & & \\
\hline 9,1 & $1 \%, 7$ & $q, r$ & $\Lambda,$. & $I V, r$ & $r \mid, \Lambda$ & $\%$ & & \\
\hline ro & ro & $T V$ & 7. & VI & 90 & العدد & \multirow{2}{*}{ ر رسمى } & \multirow{6}{*}{ المشتركُة } \\
\hline$T V, V$ & $0 \wedge, 1$ & $79, r$ & $V_{4}, q$ & $\Delta v, v$ & 90 & $\%$ & & \\
\hline$r$ & 10 & 10 & 9 & $\mathrm{v}$ & 0 & العدد & \multirow{2}{*}{ غير رسمى } & \\
\hline $0, \xi$ & $r \leqslant, q$ & $r_{\Lambda, 0}$ & 11,0 & $\Lambda, \uparrow$ & $\circ$ & $\%$ & & \\
\hline 1. & $r$ & $r$ & 9 & $r$ & صفر & العدد & \multirow{2}{*}{ مختلط } & \\
\hline$T V$, & $v$, & 0,1 & 11,0 & $r, v$ & صفر & $\%$ & & \\
\hline
\end{tabular}

الإرشاد الزراعى والمنظمات الريفية الزراعية حيث انحصرت قوة

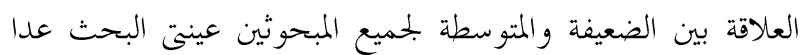

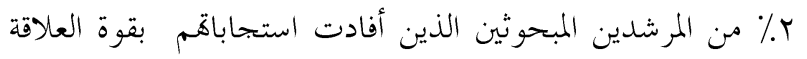

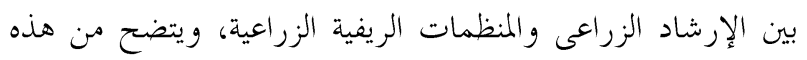
النتيجة ضرورة تكثيف الجهود للعمل على تقوية العلاقة بين الإرشاد الزراعى والمنظمات الريفية الزراعية، حيث أن جميع هذه المنظمات تدف إلى تنمية الريف من خلال بحالات عمل محددة لكلٍ منها ومعظم هذه البمالات تدخل في إطار اهتمامات العمل الإرشادى

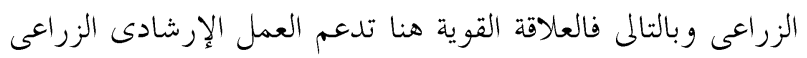
وفن ذات الوقت تساعد تلك المنظمات الزراعية على تحقيق اهدافها.
وبالنسبة لقوة العلاقة بين الإرشاد الزراعى والمنظمات الريفية

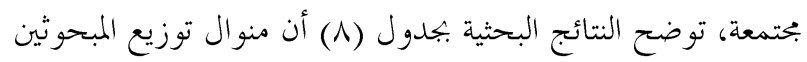

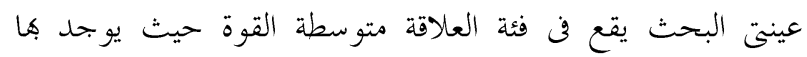

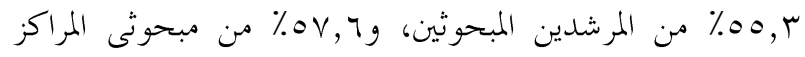
الإرشادية، يلى هذه الفئة فئة العلاقة ضعيفة القوة حيث تضم بنم \% r, Y

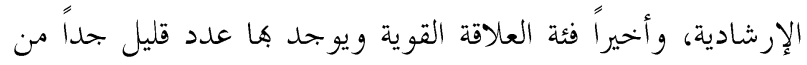
المرشدين المبحوثين تصل نسبتهمץ\% فقط، ولايوجد في هذه الفئة أى من مبحوثى المراكز الإرشادية.

وتشير هذه النتائج بصفة عامة إلى الخخاض قوة العلاقة بين

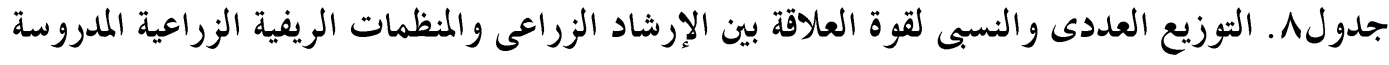

\begin{tabular}{|c|c|c|c|c|}
\hline \multicolumn{2}{|c|}{ العاملون الإرشاديون بالمراكز الإرشادية } & \multicolumn{2}{|c|}{ المرشدون الزراعيون على مستوى القرية } & \multirow{2}{*}{ الفئـــــــــات } \\
\hline$\%$ & العدد & $\%$ & العدد & \\
\hline$\varepsilon r, \varepsilon$ & T^ & $\varepsilon r, V$ & 70 & ضعيفة ( صفر- ^ ) \\
\hline ov, $\mathrm{T}$ & rی & $00, \mu$ & $\wedge \varepsilon$ & متوسطة ( 9 - | | ) \\
\hline صفر & صفر & $r, \cdot$ & r & قـــويـــــ (Y \\
\hline $1 \ldots$ & 77 & $1 \ldots$ & $10 Y$ & الإجمالي \\
\hline
\end{tabular}


وبالنسبة لترتيب المعوقات لمبحوثى المراكز الإرشادية فجاءت

مرتبة تنازلياً على النحو التالى: عدم وجود تنسيق بين المنظمات الريفية الزراعية والإرشاد الزراعى يتيح تبادل المعلومات فيما بينهم

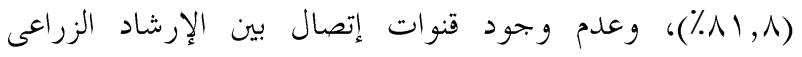

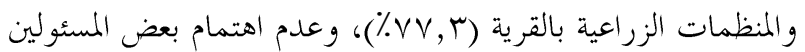
بالمنظمات الريفية الزراعية لأهمية تبادل المعلومات مع الرعات الإرشاد

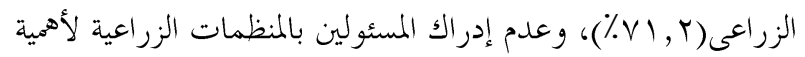
تبادل المعلومات مع الإرشاد الزراعى (19,7\%). و كانت أقل المعوقات أهمية متمثلة في: ضعف الثقة بين الإرشاد الزراعى والمنظمات الريفية الزراعية(0, (٪)، ثم عدم توافر وسائل الاتصال

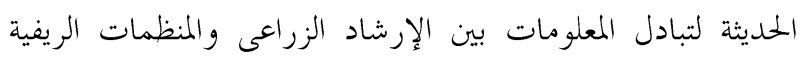

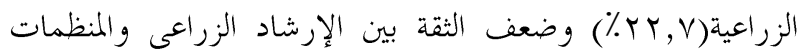

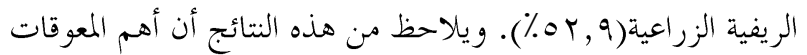

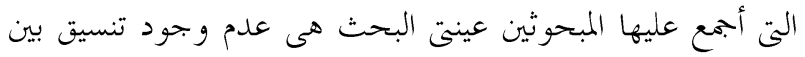

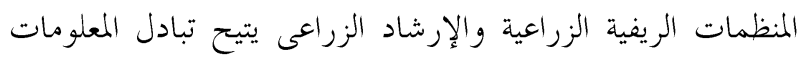

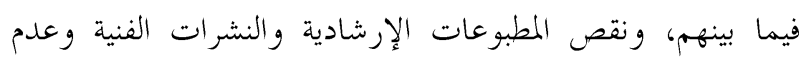
تداولها بين الإرشاد والمنظمات الريفية الزراعية، وعدم اهتمام بعض إلرض

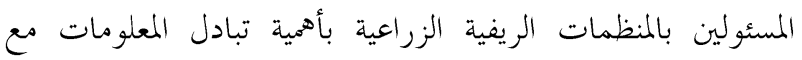
الإرشاد الزراعى.
ثانيا: المعوقات التى تحد من وجود علاقات فعالة بين الإرشاد الزراعى والمنظمات الريفية الزراعية: (أ) المعوقات التى تحد من تبادل المعلومات بين الإرشاد الزراعى لمات لمات والمنظمات الريفية الزراعية: توضح النتائج البحثية بجدول(9) أن أهم المعوقات التي تحد من تبادل المعلومات بين الإرشاد الزراعى والمنظمات الريفية الزراعية

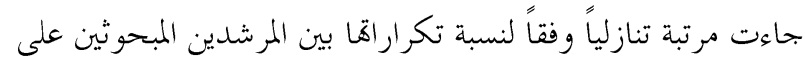
النحو التالى: عدم وجود تنسيق بين المنظمات الزراعية والإرشاد

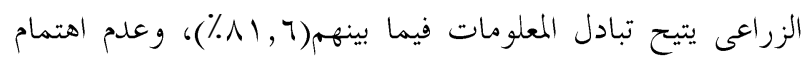

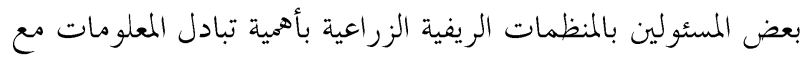

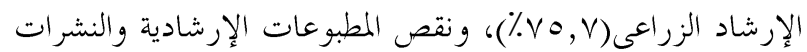

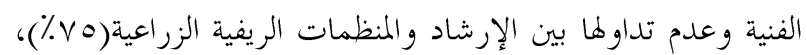

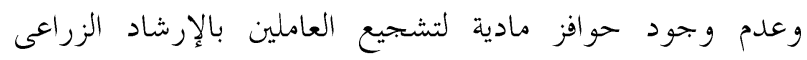

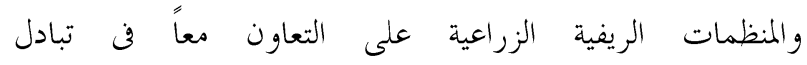
المعلومات(r

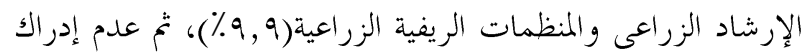

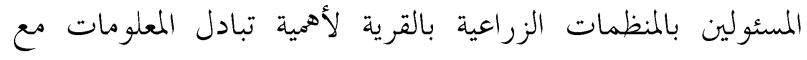

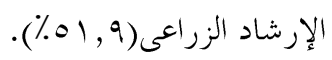

جدول 9 ـ معوقات تبادل المعلومات بين الإرشاد الزراعى والمنظمات الريفية الزراعية

\begin{tabular}{|c|c|c|c|c|c|c|c|}
\hline \multicolumn{3}{|c|}{ بالماملون الإرشادشيونِ } & \multicolumn{3}{|c|}{ المرشدون الز القيوية على مستى } & \multirow{2}{*}{ 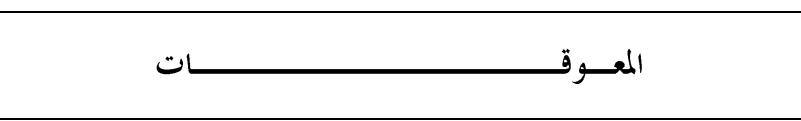 } & \multirow[t]{2}{*}{ p } \\
\hline توتيب & $\%$ & عدد & توتيب & $\%$ & عدد & & \\
\hline r & $\checkmark \vee, r$ & 01 & V & vi, 1 & $1 \cdot 1$ & بالقرمية. وجود قنوات إتصال فعالة بين الإرشاد الزراعى والمنظمات الزراعية & 1 \\
\hline$\mu$ & $V \varepsilon, Y$ & $\varepsilon 9$ & $r$ & $v_{0}, \cdot$ & $11 \varepsilon$ & الزعص المطبو والمنظمات الإزشادية والنشرات الفنية وعدم تداولها بين الإرشـــاد & r \\
\hline V & $70, Y$ & $\varepsilon r$ & 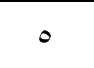 & $V r, \varepsilon$ & 11. & 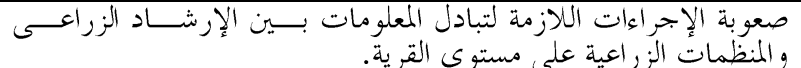 & r \\
\hline$\varepsilon$ & $V_{1, r}$ & $\varepsilon V$ & r & $v_{0}, v$ & 110 & 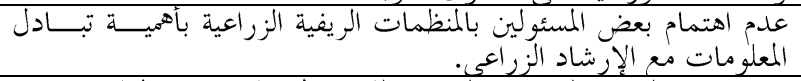 & $\varepsilon$ \\
\hline 7 & $\mathrm{~T}, \mathrm{~V}$ & $\varepsilon \varepsilon$ & 9 & $09, r$ & 9. & 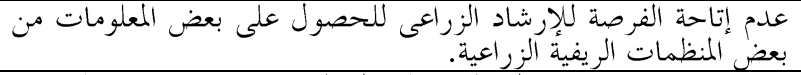 & 0 \\
\hline 1. & $r, v$ & 10 & 7 & $\mathrm{v}, \mathrm{v}$ & 1.9 & و المنظمات توات الر يفئل الز الاتصالة الحديثة لتبادل المعلومات بين الإرشاد الزراعى & 7 \\
\hline 0 & $79, v$ & $\sum 7$ & 1. & 01,9 & vq & 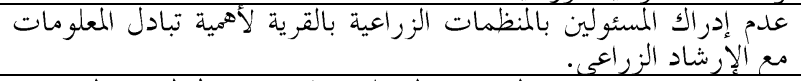 & V \\
\hline$\Lambda$ & $7 \pi, 7$ & $\varepsilon r$ & $\varepsilon$ & $v \varepsilon, r$ & $11 \pi$ & 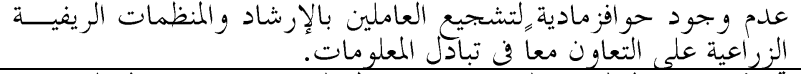 & $\wedge$ \\
\hline 9 & $7 \cdot, 7$ & $\varepsilon$. & $\Lambda$ & $7 \Lambda, \varepsilon$ & $1 . \varepsilon$ & تتوف بعض المنظمات الزراعية من تداول البيانات خاصة بنوك القرى. & 9 \\
\hline 1 & $\wedge 1, \wedge$ & $0\}$ & 1 & 1,7 & $1 Y \varepsilon$ & المعلومات وجود تنسيق بينهم. بين المنظمات الزراعية والإرشاد الزراعى يتيح تبادل & 1. \\
\hline 11 & 1,0 & 1 & 11 & 9,9 & 10 & ضعف الثقة بين الإرشاد الزراعى و المنظمات الريفية الزراعية. & 11 \\
\hline
\end{tabular}


الإرشادية الزراعية على النحو التالى: كثرة وتعقد الإجراءات

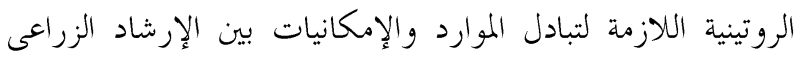

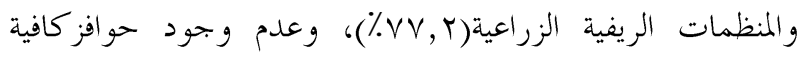
لتشجيع العاملين بالإرشاد للتعاون مع المنظمات الريفية في تبادل

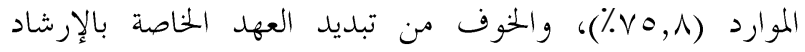

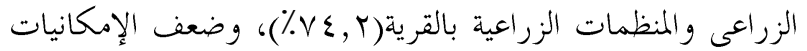

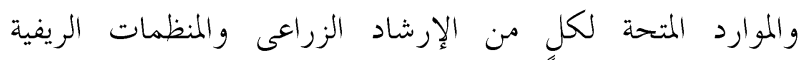

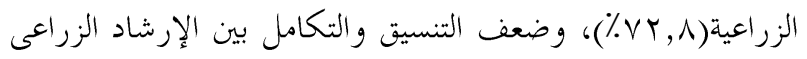

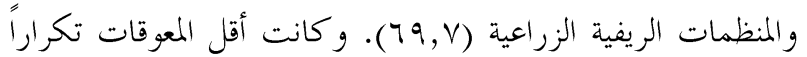
بين مبحوثى المراكز الإرشادية هى: بعد المسافة بين مقرالعمل

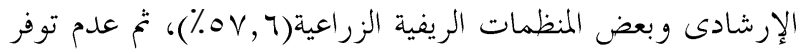

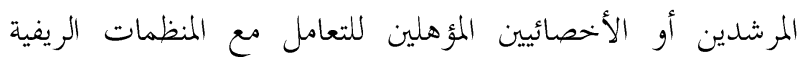

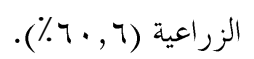

يتضح من هذه النتائج أن اهم المعوقات التي أجمع عليها المبحوثين عينتى البحث هى: كثرة وتعقد الإجراءات الروتينية

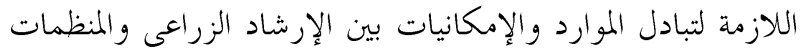

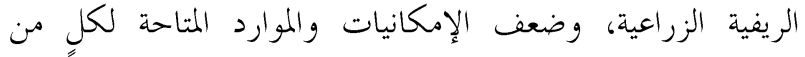

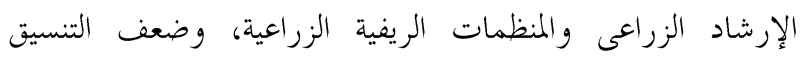
والتكامل بين الإرشاد الزراعى والمنظمات الريفية الزراعية.

\section{(ب)المعوقات التى تحد من تبادل الموارد بين الإرشاد الزراعى

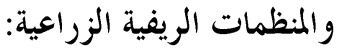

تشيرالنتائج البحثية بجدول( • (1أن أهم المعوقات التي تحد من

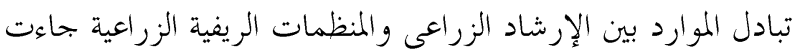

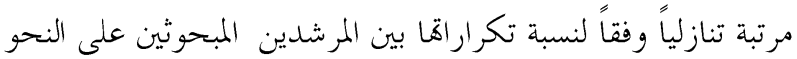
التالى: كثرة وتعقد الإجراءات الروتينية اللازمة لتبادل الموارد بين الإرشاد الزراعى والمنظمات الريفية (^,^^^٪)، وضعف التنسيق

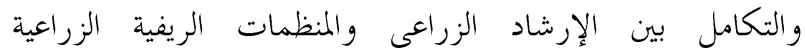

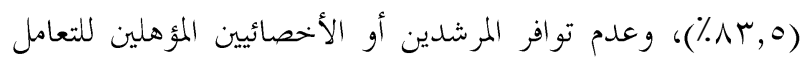

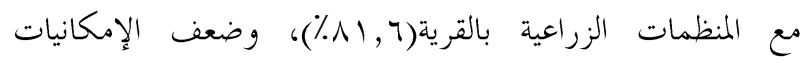
والموارد المتاحة لكلٍ من الإرشاد الزراعى والمنظمات الريفية

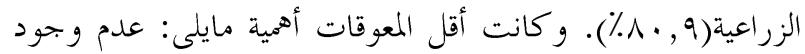

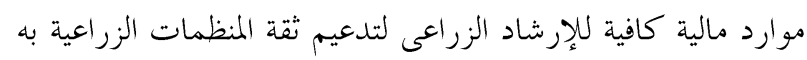

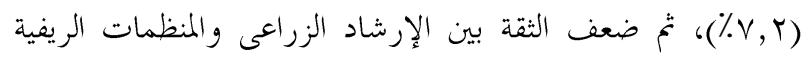
الزراعية فيما يتعلق بتبادل الموارد (^, (r؟٪). وكان ترتيب أهم المعوقات المؤثرة على تبادل الموارد بين

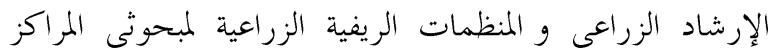

جدول • 1 . معوقات تبادل المعلومات بين الإرشاد الزراعى والمنظمات الريفية الزراعية

\begin{tabular}{|c|c|c|c|c|c|c|c|}
\hline \multicolumn{3}{|c|}{ العاملون الإرشاديون } & \multicolumn{3}{|c|}{ المرشدون الزراعيون على القرية } & \multirow{2}{*}{ 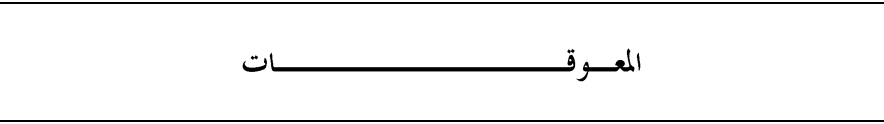 } & \multirow[t]{2}{*}{$\hat{c}$} \\
\hline توتيب & $\%$ & 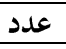 & ترتيب & $\%$ & 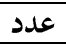 & & \\
\hline 1 & $V V, r$ & 01 & 1 & $\wedge \neg, \wedge$ & ITt & 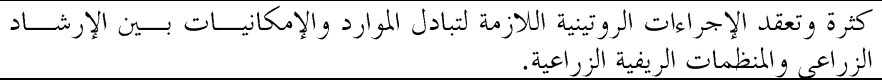 & 1 \\
\hline$\varepsilon$ & $V Y, \wedge$ & $\varepsilon \wedge$ & $\varepsilon$ & $1 \cdot, 9$ & r & ضعف الإمكانيات والموارد المتحة لكل من الإرشاد الزراعى والمنظمات الريفية الزراعية. & r \\
\hline V & Tr, & $\varepsilon r$ & 1. & $7 \pi, \wedge$ & $9 \mathrm{~V}$ & ضيما بينهم. الثقة بين الإرشاد الزراعى والمنظمات الريفية الزراعية فيما يتعلق بتيادل المـــوارد & r \\
\hline 0 & $97, \mathrm{~V}$ & $\varepsilon\rceil$ & r & Ar,o & $1 \mathrm{iV}$ & ضعف التنسيق والتكامل بين الإرشاد الزراعى والمنظمات الريفية الزراعية. & $\varepsilon$ \\
\hline$r$ & $V \varepsilon, r$ & $\varepsilon q$ & $\mathrm{v}$ & $V \cdot, \Sigma$ & $1 \cdot v$ & الخو ف من تبديد العهد الخاصة بالإرشاد الزراعى والمنظمات الزراعية القرية. & $\circ$ \\
\hline 9 & $7 \cdot, 7$ & $\varepsilon$. & $r$ & 11,7 & $1 Y \varepsilon$ & عدم تو افر المرشدين أو الأخصائيين المؤهلين للتعامل مع المنظمات الزراعية بالقرية. & 7 \\
\hline 1. & ov, 1 & rᄉ & 9 & $7 V, 1$ & $1 \cdot r$ & بعد المسافة بين مقر العمل الإرشادى وبعض المنظمات اليفية الزراعية. & $\mathrm{V}$ \\
\hline 7 & $\tau$ ז & $\varepsilon r$ & ○ & $v \varepsilon, r$ & 114 & 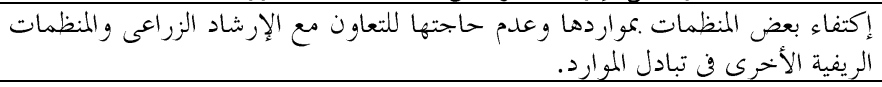 & $\wedge$ \\
\hline r & $\vee \bullet, \wedge$ & o. & 7 & $\vee r, v$ & $11 \mathrm{r}$ & الموارد وجود حو افز كافية لتشجيع العاملين بالإرشاد للتعاون مع المنظمات الريفية في تبادل & 9 \\
\hline$\wedge$ & $7 r, 1$ & $\varepsilon 1$ & $\wedge$ & $T V, V$ & $1 \cdot r$ & تبادل المو ارد المرونة الإمكانياتية لدى بعض المسئولين بالمنظمات الزراعية للتعاون مع الإرشاد في & $1 \cdot$ \\
\hline 11 & صفر & صغر & 11 & $V, r$ & 11 & عدم وجود موارد مالية كافية للإرشاد الزراعى لتدعيم ثقة المنظمات الزراعية به. & 11 \\
\hline
\end{tabular}


حو افزللعاملين بالمنظمات الزراعية للإشتراك مع الإرشاد الزراعى في

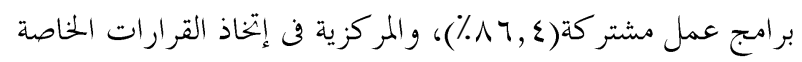

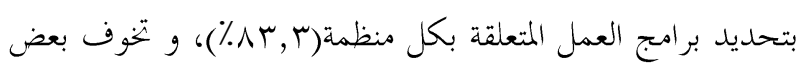

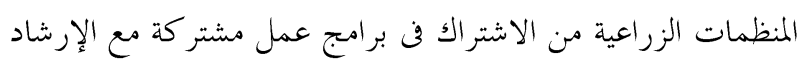

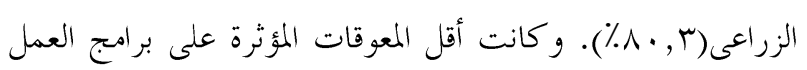

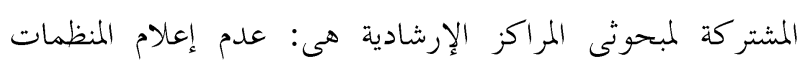

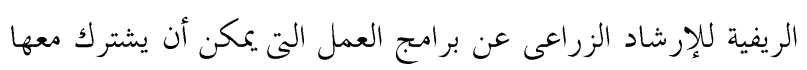

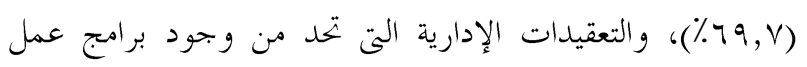

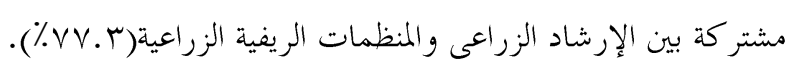

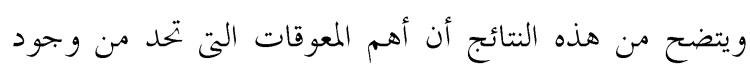

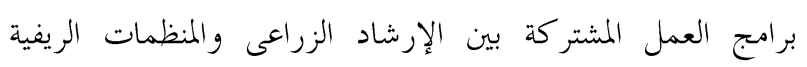

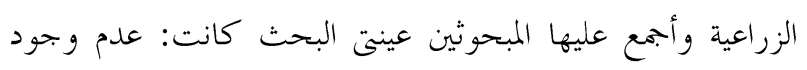

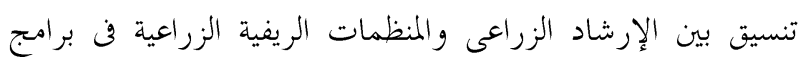

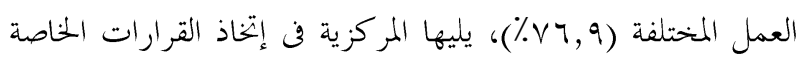

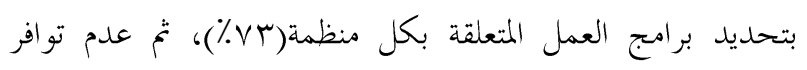

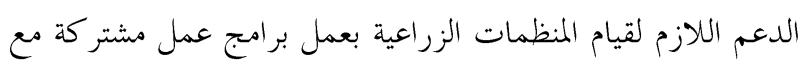

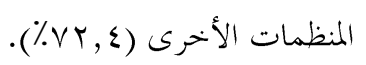

يتضح من دراسة المعوقات التئ تحد التي تحد من زيادة فعالية العلاقات بين الإرشاد الزراعى والمنظمات الريفية الزراعية أن هناك دئك المعات
(جـ) المعوقات التى تحد من وجود برامج العمل المشتركة بين الإرشاد الزراعى والمنظمات الريفية الزراعية:

يتضح من النتائج البحثية بجدول(1) (1) أن أهم المعوقات التئ

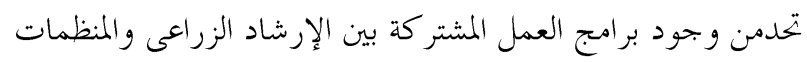

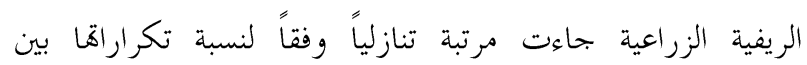
المرشدين المبحوثين على النحو التالى: عدم وجود تنسيق بين الإرشاد

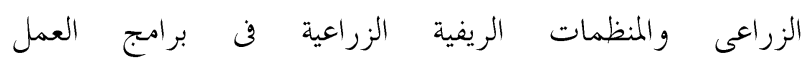

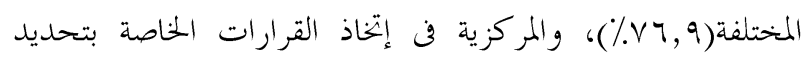

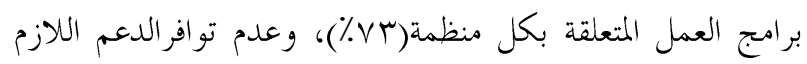

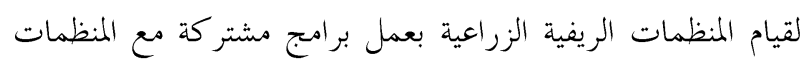

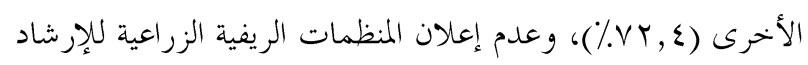

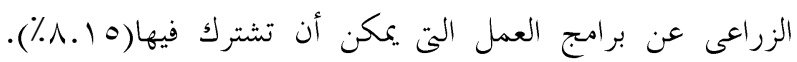

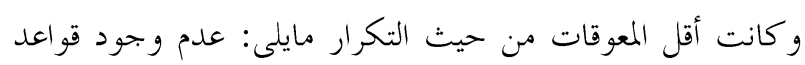

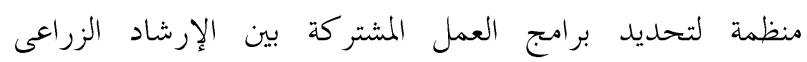
والمنظمات الزراعية كل فيما يخصه (r, به \%)، والتعقيدات الإدارية

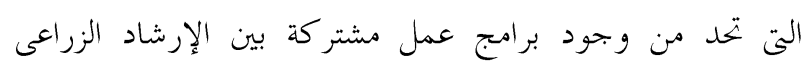

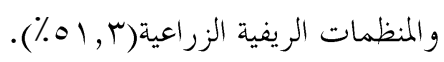

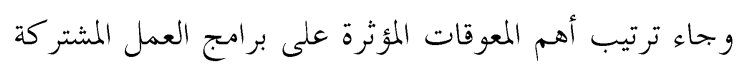

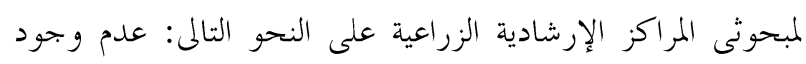

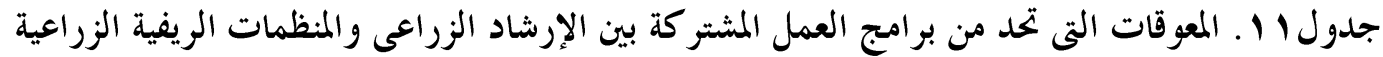

\begin{tabular}{|c|c|c|c|c|c|c|c|}
\hline \multicolumn{3}{|c|}{ العاملون الإرشاديون بالمراكز } & \multicolumn{3}{|c|}{ 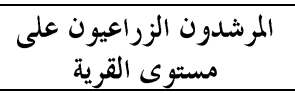 } & \multirow[t]{2}{*}{ 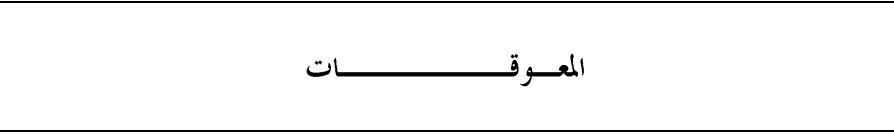 } & \multirow[t]{2}{*}{$\hat{\imath}$} \\
\hline ترتيب & $\%$ & 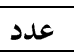 & ترتيب & $\%$ & 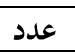 & & \\
\hline$r$ & $\wedge 1, \wedge$ & $0 \leqslant$ & 1 & $V_{7}, 9$ & $11 \mathrm{~V}$ & عدم وجود تنسيق بين الإرشاد الزراعى والمنظمات الريفية الزراعية في برامج العمل. & 1 \\
\hline V & $\gamma \vee, r$ & 01 & V & $01, r$ & $v_{\Lambda}$ & والمنظميدات الإِدارية الزئت تحد من وجود برامج عمل مشتر كة بــين الإرشــاد الزراعـى & $r$ \\
\hline$r$ & $\Delta r, r$ & 00 & r & $\mathrm{Vr}$ & 111 & المركزية في إتخاذ القر ارات الخاصة بتحديد برامجج العمل المتعلقة بكل منظمة & $r$ \\
\hline 1 & $\Lambda_{\nearrow}, \varepsilon$ & or & 。 & $\wedge 0,0$ & $\wedge 9$ & مشتر وبة . & \\
\hline$\varepsilon$ & $\lambda \cdot, r$ & or & 7 & $0 \leqslant, 7$ & $\lambda r$ & 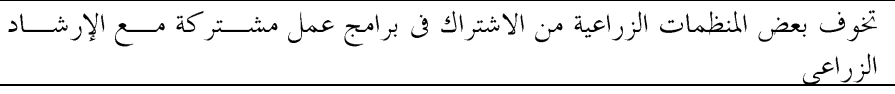 & \\
\hline 0 & $\vee \wedge, \wedge$ & or & $r$ & $V Y, \xi$ & 11. & الأخدرى توافر الدعم اللازم لقيام المنظمات الزراعية بعمل برامج مشتر كة مــع المنظمـــات & 7 \\
\hline$\wedge$ & $79, \mathrm{~V}$ & $\sum 7$ & $\varepsilon$ & 70,1 & $1 \ldots$ & 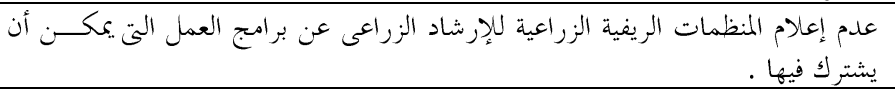 & \\
\hline 7 & $\vee \wedge, \wedge$ & or & $\wedge$ & or,r & 11 & الز راعية كول فيما يخصده منظمة لتحديد برامج العمل المشتر كة بين الإرشاد الزراعى والمنظمات & \\
\hline
\end{tabular}


والمنظمات الريفية الزراعية تضمن تبادل المعلومات فيما بينهم

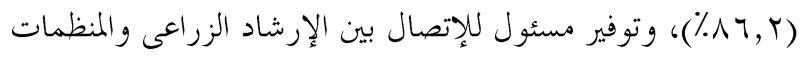
الريفية الزراعية(r,ی,^٪)، وتوفيروتسهيل وسائل للإتصال بين

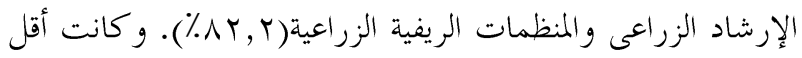

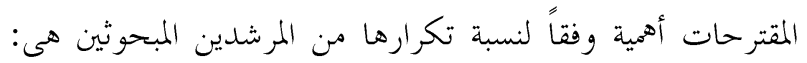

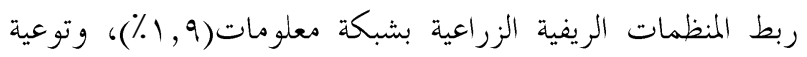
العاملين بالمنظمات الريفية الزراعية بالدور الذى يلعبه الإرشاد

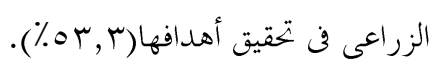

وبالنسبة لأهم مقترحات مبحوثى المراكز الإرشادية فجاءت

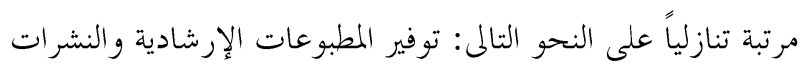

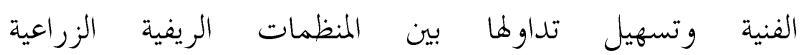

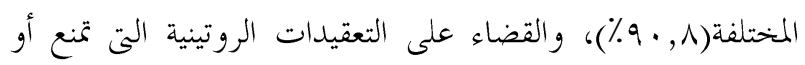

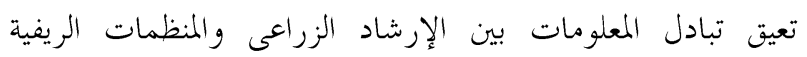

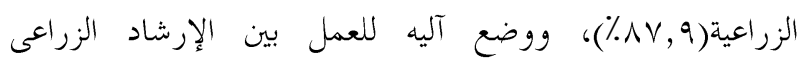

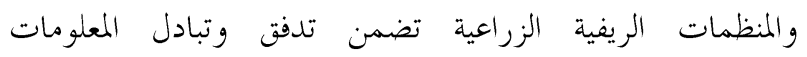

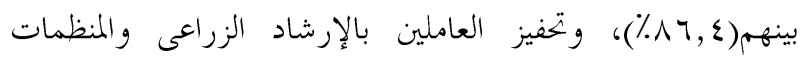

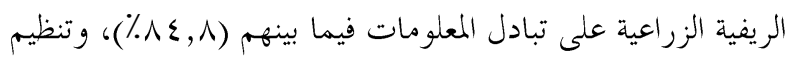

تقارب لحد كبير بين وجهتى نظر المبحوثين عينتى البحث فيها مما

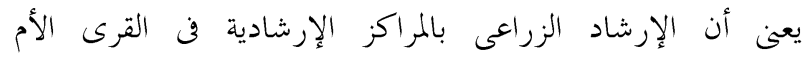

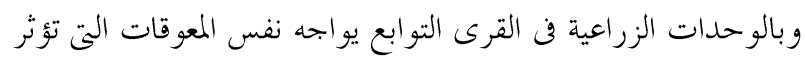

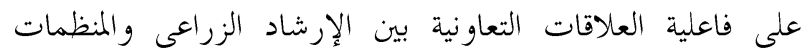
الريفية الزراعية.

ثالثاً: مقترحات المبحوثين لزيادة فعالية العلاقة بين الإرشاد الزراعى والمنظمات الريفية الزراعية:

(أ) مقترحات المبحوثين لزيادة فعالية العلاقة فى تبادل المعلومات بين الإرشاد الزراعى والمنظمات الريفية الزراعية: يتضح من النتائج البحثية بجدول(r I) أن أهم مقترحات المرشدين المبحوثين لزيادة فعالية علاقة تبادل المعلومات بين الإرشاد

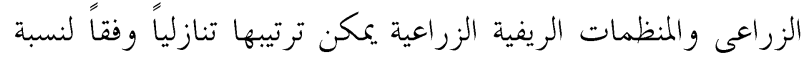

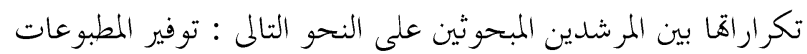

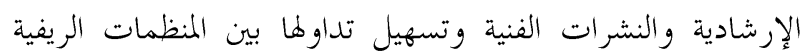

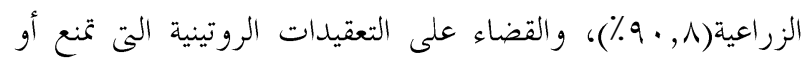

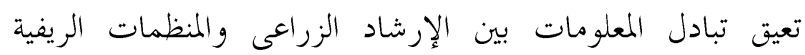

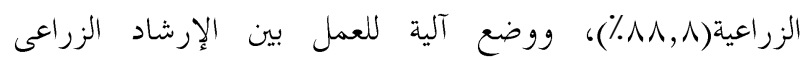

جدول Y I ـ مقترحات المبحوثين لزيادة فعالية علاقة تبادل المعلومات بين الإرشاد و المنظمات الريفية الزراعية

\begin{tabular}{|c|c|c|c|c|c|c|c|}
\hline \multicolumn{3}{|c|}{ العاملون الإرشاديون } & \multicolumn{3}{|c|}{ المرشدون الزراعيون على القرية } & \multirow[t]{2}{*}{ 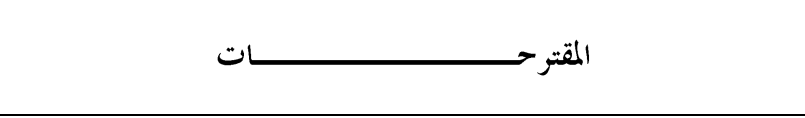 } & \multirow[t]{2}{*}{ ? } \\
\hline 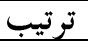 & $\%$ & 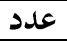 & ترتيب & $\%$ & 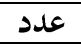 & & \\
\hline$\varepsilon$ & $\wedge \varepsilon, \wedge$ & 04 & 9 & $\mathrm{TV}, \Lambda$ & $1 \cdot r$ & المعلوميز العاملينه بالإرشاد الزراعى والمنظمات الريفية الزراعية على تبــادل & 1 \\
\hline$\wedge$ & $V \varepsilon, Y$ & $\varepsilon 9$ & $\checkmark$ & $V r, \mathrm{~V}$ & 115 & وبين الإرشاد الزراعى. توعلمات الريفية الزراعية بأهمية تبادل المعلومات بينــها & r \\
\hline 9 & $V T, Y$ & $\varepsilon \wedge$ & 0 & $\Delta r, r$ & $1 \% 0$ & توفير وتسهيل وسائل الإتصال بين الإرشاد و المنظمات الريفية الزراعية. & $r$ \\
\hline 1 & ᄉ $9, r$ & 09 & 1 & $9 \cdot, \wedge$ & IT & الريفية المطبوعاتية الإرشادية و النشر ات الفنية وتسهيل تداولها بين المنظمات & $\varepsilon$ \\
\hline 1. & 09 & rq & 1 . & or, r & 11 & 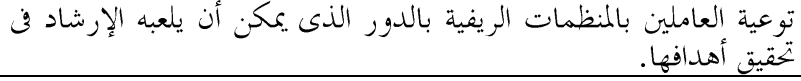 & 0 \\
\hline 7 & $\vee \wedge, \wedge$ & or & 7 & $\vee \wedge, q$ & Ir. & الزراعية. إجتماعات ولقاءات دورية للعاملين بالإرشاد و المنظمات الريفيــة & 7 \\
\hline 。 & $\wedge 1, \wedge$ & $0\}$ & $\wedge$ & $V T$ & 111 & تلزظيم دورات تدريبية مشتركة للعاملين بالإرشاد و المنظمــات الريفيــة & $V$ \\
\hline r & $\wedge \vee, q$ & $0 \wedge$ & r & $\wedge \wedge, \wedge$ & tro & 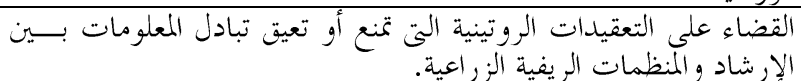 & $\Lambda$ \\
\hline $\mathrm{V}$ & $V \vee, r$ & 01 & $\varepsilon$ & $\Lambda \varepsilon, r$ & IrA & توفير مسئول للإتصال بين الإرشاد الزراعى والمنظمات الريفية. & 9 \\
\hline$r$ & $\Lambda_{\top} \uparrow, \varepsilon$ & ov & $r$ & $\Lambda \uparrow, r$ & $|\pi|$ & 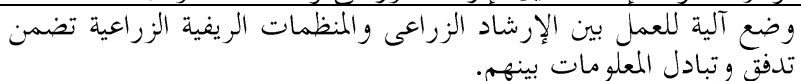 & 1. \\
\hline 11 & $19, \mathrm{~V}$ & 14 & 11 & 1,9 & $r$ & ربط المنظمات الزراعية الريغية بالقرية بشبكة معلومات. & 11 \\
\hline
\end{tabular}




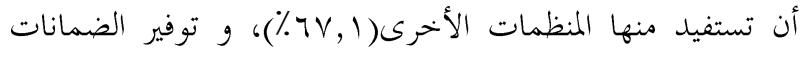

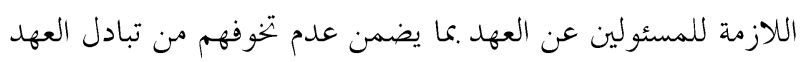

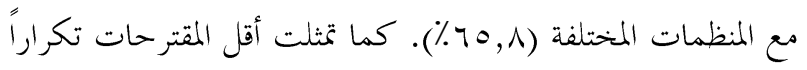
بالنسبة للمرشدين المبحوثين في توعية العاملين بالإرشاد والمنظمات

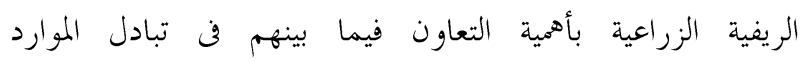
والإمكانيات(9 (101\%)، وتوفير أخصائيين إرشاديين بالقرى للتعامل

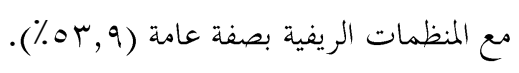
أما بالنسبة لترتيب أهم مقترحات زيادة فاعلية العلاقة في تبادل الموارد والإمكانيات بين الإرشاد والمنظمات الريفية الزراعية وفقاً

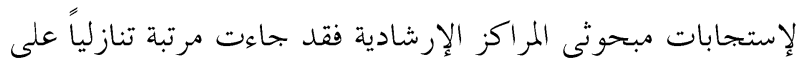

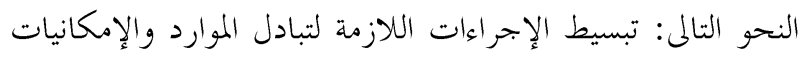

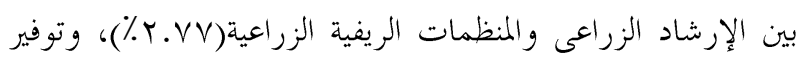

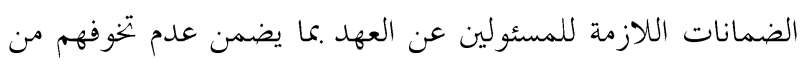

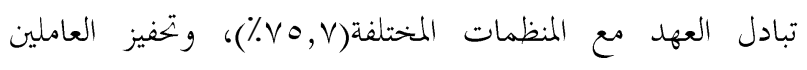
بالإرشاد والمنظمات الريفية الزراعية على تبادل الموارد والإمكانيات

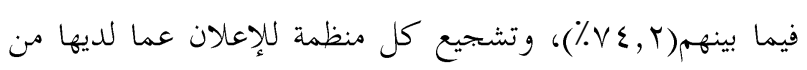

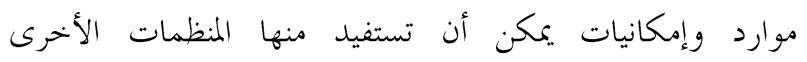

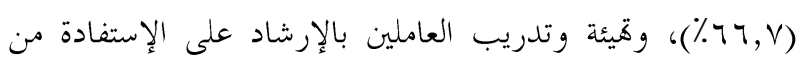

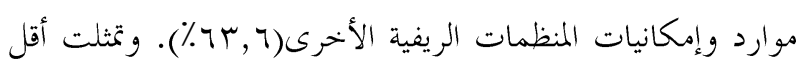

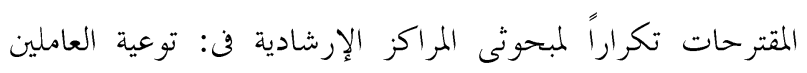

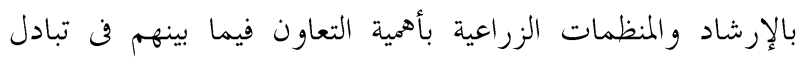

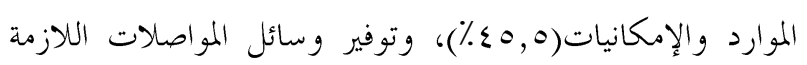

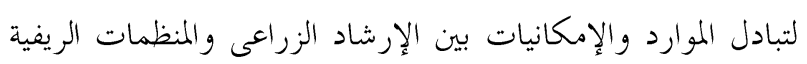

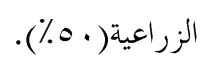

ويلاحظ من هذه النتائج أن هناك إتفاق بين المبحوثين عينتى

البحث على أن أهم المقترحات لزيادة فعالية علاقة تبادل الموارد بين

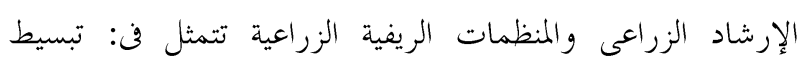

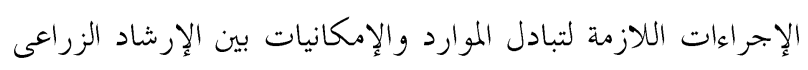

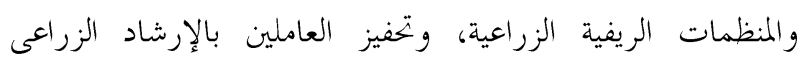

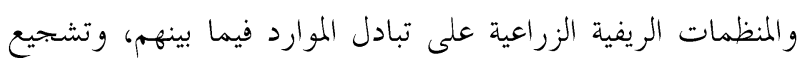

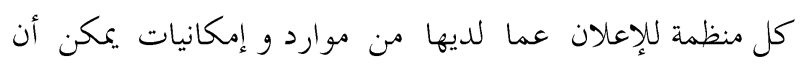

دورات تدريبية مشتركة للعاملين بالإرشاد والمنظمات الريفية الزراعية(^, 1, 1\%). و كانت أقل المقترحات أهمية وفقاً لنسبة تكرارها

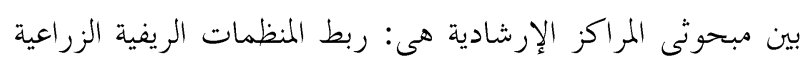

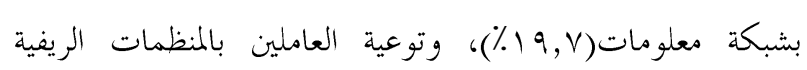

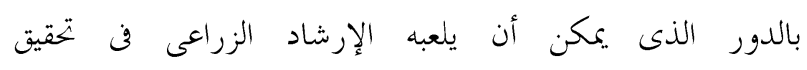
أهدافها (1.09).

يتضح من هذه النتائج أن أهم مقترحات زيادة فاعلية علاقة تبادل المعلومات بين الإرشاد الزراعى والمنظمات الريفية الزراعية

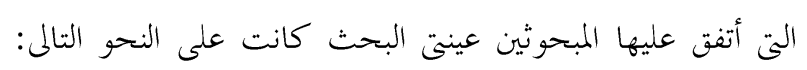

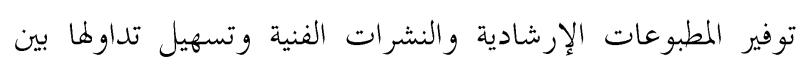

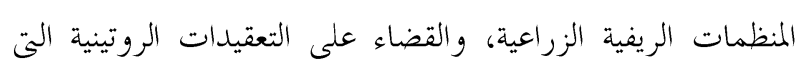

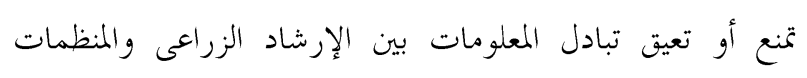

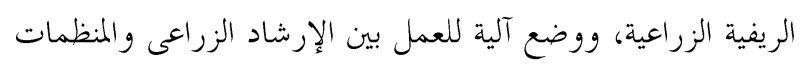

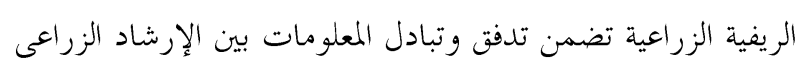

$$
\text { والمنظمات الريفية الزراعية. }
$$

كما أن هناك إتفاقاً بين عينتى البحث بالنسبة لأقل المقترحات المات

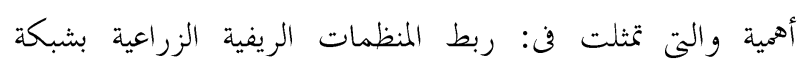

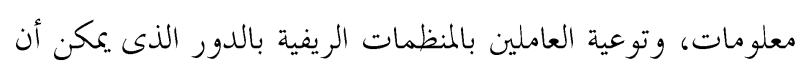
يلعبه الإرشاد الزراعى في تحقيق أهدافها.

\section{(ب)مقترحات المبحوثين لزيادة فعالية علاقة تبادل الموارد بين} الإرشاد الزراعى والمنظمات الريفية الزراعية:

تشير النتائج البحثية بجدول(r آ) أن أهم مقترحات زيادة فاعلية علاقة تبادل الموارد بين الإرشاد الزراعى والمنظمات الريفية الزراعية

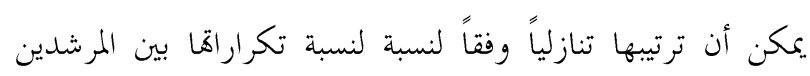
المبحوثين على النحو التالى: تبسيط الإجراءات اللازمة لتبادل الموارد

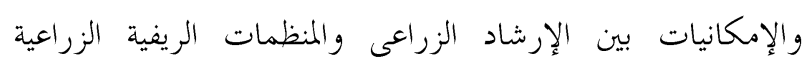

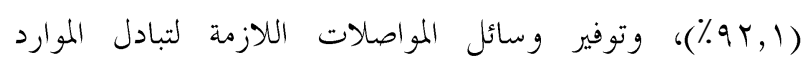

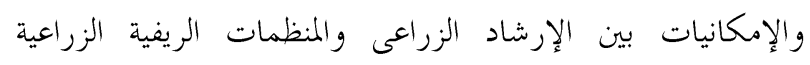

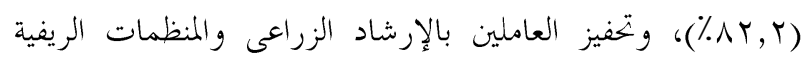

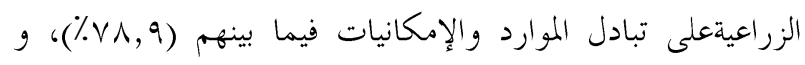

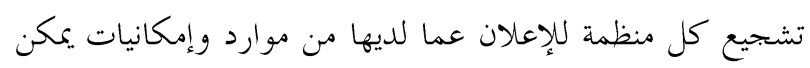


جدول ا ا ـ مقترحات المبحوثين لزيادة فعالية علاقة تبادل الموارد بين الإرشاد والمنظمات الريفية الزراعية

\begin{tabular}{|c|c|c|c|c|c|c|c|}
\hline \multicolumn{3}{|c|}{ العاملون الإرشاديون بالمراكز } & \multicolumn{3}{|c|}{ المرشدون الزراعيون على القرية } & \multirow[t]{2}{*}{ 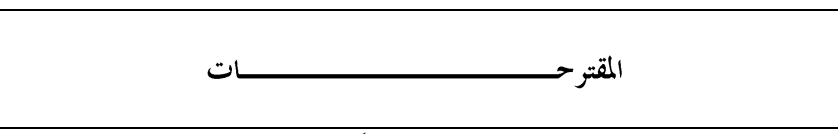 } & \multirow[t]{2}{*}{$\hat{\beta}$} \\
\hline ترتيب & $\%$ & 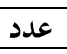 & ترتيب & $\%$ & 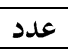 & & \\
\hline 1 & $V Y, r$ & 01 & 1 & 94,1 & $1 \varepsilon$. & 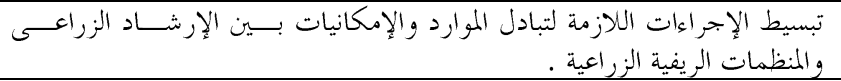 & 1 \\
\hline V & $7 r, 1$ & \&1 & 7 & 70,1 & 99 & أأن تحدى وتوضح كل منظمة ريفية قواعد وإجراءات تبادل مواردها مع المنظمات & r \\
\hline 9 & 0. & Tr & r & $\Delta r, r$ & ITO & تالريفية وسائل الموصلات اللازمة لتبادل الموارد والأمكانيات بين الإرشاد والمنظمات & $r$ \\
\hline$\mu$ & $V \varepsilon, Y$ & $\varepsilon 9$ & $r$ & $\vee \wedge, q$ & Ir. & فيما بينهم . تعاملين بالإرشاد والمنظمات الريفية الزراعية على تبادل الموارد والإمكانيات & $\varepsilon$ \\
\hline$\varepsilon$ & $77, \mathrm{~V}$ & $\varepsilon \varepsilon$ & $\varepsilon$ & $T V, 1$ & $1 \cdot r$ & تشنيع كل منظمة للإعلان عما لديها من موارد و إمكانيات يمكن أن تستفيد منها & 。 \\
\hline r & $v_{0}, v$ & 0. & 。 & 70,1 & $1 \ldots$ & توفير الضمانات اللازخلفة للمسئولين عن العهد .مما يضمن عدم تخوفهم من تبـادل & 7 \\
\hline$\Lambda$ & 09,1 & ra & 9 & or, q & Ar & توفير أخصائيين إرشاديين بالقرى للتعامل مع المنظمات الريفية . & $\mathrm{v}$ \\
\hline 。 & T T, & $\varepsilon r$ & v & גור & $9 \varepsilon$ & الأيئة وتدريب العاملين بالإرشاد الزراعى على الإستفادة من موارد المنظمات الريفية & $\wedge$ \\
\hline 7 & 70,1 & $\varepsilon r$ & $\wedge$ & $00, r$ & $\wedge \varepsilon$ & 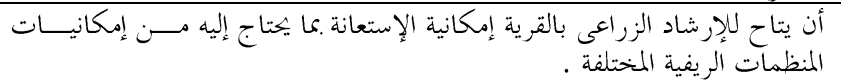 & 9 \\
\hline 1. & $\{0,0$ & $r$. & 1. & 01,9 & 19 & 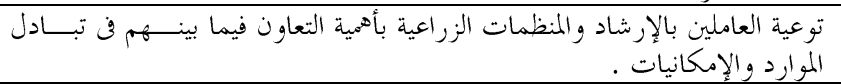 & \\
\hline
\end{tabular}

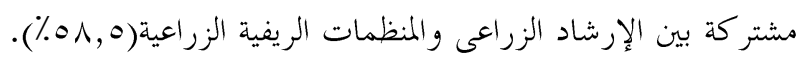

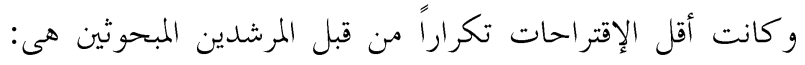

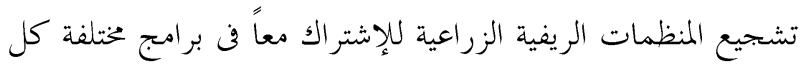
فيما يخصه(r,ه \%)، وعقد إجتماعات دورية للعاملين بالإرشاد

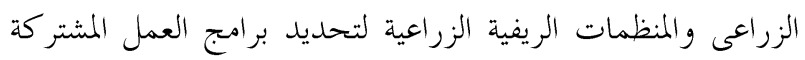

$$
\text { بينهم (9, 9.9. }
$$

وبالنسبة لترتيب مقترحات زيادة فعالية علاقة برامج العمل المشتركة بين الإرشاد الزراعى والمنظمات الريفية الزراعية لمبحوثى

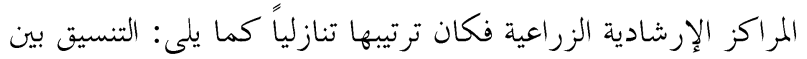
المنظمات الريفية على مستوى القرية في تخطيط وتنفيذ برامج العمل

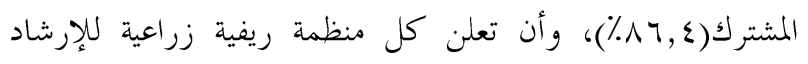

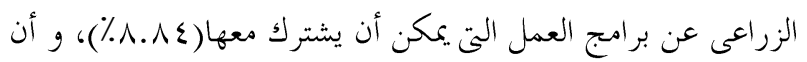

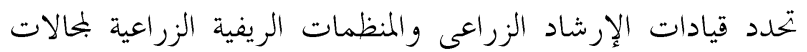

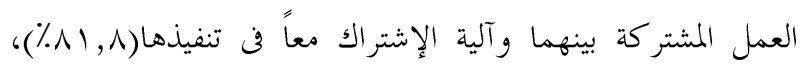

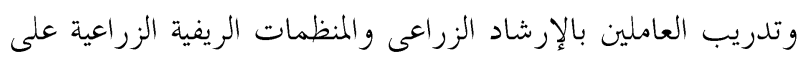

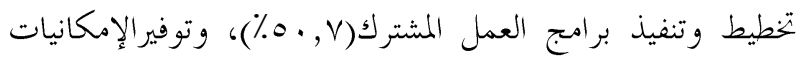
والدعم اللازم للقيام ببرامج عمل مشتركة بين الإرشاد الزراعى
تستفيد منها المنظمات الأخرى. كما تمثلت أقل المقترحات بالنسبة

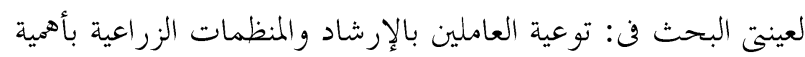

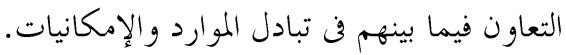

(جس)مقترحات المبحوثين لزيادة فعالية العلاقة فى برامج العمل المشتر كة بين الإرشاد الزراعى والمنظمات الريفية الزراعية: توضح النتائج البحثية بجدول(ع ( ) أن أهم مقترحات المرشدين

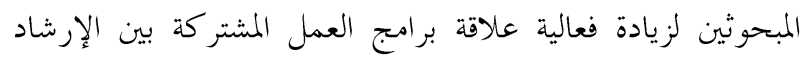

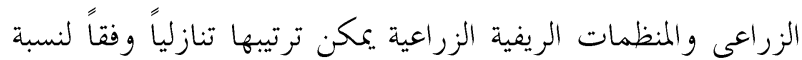
تكراراتا بين المبحوثين على النحو التالى: تقديم حوافز مميزة للعاملين

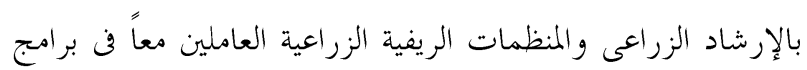

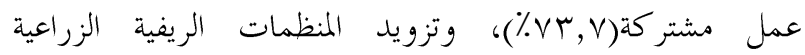

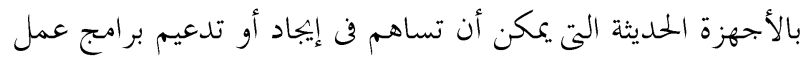

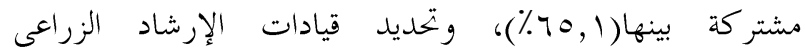
والمنظمات الريفية الزراعية بلمالات العمل المشتركة بينهما وآلية

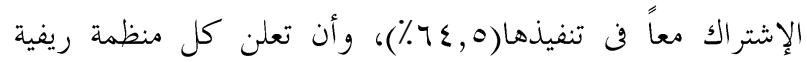
زراعية لإرشاد الزراعى عن برامج العمل التئ يمكن أن يشترك فيها

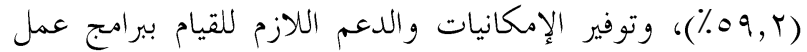


جدول \& ا ـ مقترحات المبحوثين لزيادة فعالية علاقة برامج العمل المشتركة بين الإرشاد الزراعى والمنظمات الريفية الزراعية

\begin{tabular}{|c|c|c|c|c|c|c|c|}
\hline \multicolumn{3}{|c|}{ العاملون الإرشاد يونة الإرشية } & \multicolumn{3}{|c|}{ المرشدون الز القيون على مستى } & \multirow[t]{2}{*}{ 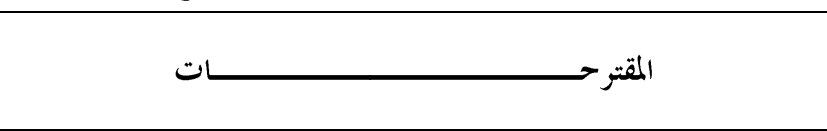 } & \multirow[t]{2}{*}{ b } \\
\hline ترتيب & $\%$ & عدد & توتيب & $\%$ & 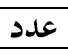 & & \\
\hline 7 & $V \varepsilon, r$ & $\varepsilon 9$ & 1 & $\mathrm{VT}, \mathrm{V}$ & $11 \mathrm{r}$ & 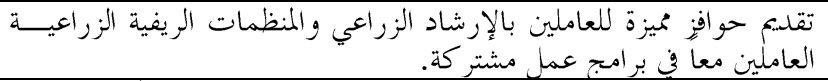 & 1 \\
\hline . & $v i, r$ & $\varepsilon v$ & 9 & $\varepsilon \wedge, \vee$ & $v \varepsilon$ & 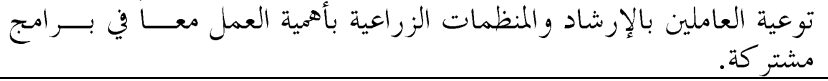 & r \\
\hline 1 . & $\varepsilon\rceil, 9$ & m & 1 . & $\{7,1$ & $v \cdot$ & والمنظماء على المعوقات التي تعيق وجود برامج عمل مشتر كة بين الإرشـــاد & r \\
\hline 1 & ᄉ५, 乏 & ov & 7 & ov, 9 & $\wedge \wedge$ & العمل المشترك كئ المنظمات الزراعية على مستوى القرية في تخطيط وتنفيذ برامج & $\varepsilon$ \\
\hline r & $\wedge \varepsilon, \wedge$ & 04 & $\varepsilon$ & $09, r$ & $9 \cdot$ & يمكن أن يشتر كك فيها. ريفية زراعية للإرشاد الزراعي عن برامج العمل الــتي & . \\
\hline ० & $\vee V, r$ & 01 & ० & $0 \wedge, 0$ & 19 & 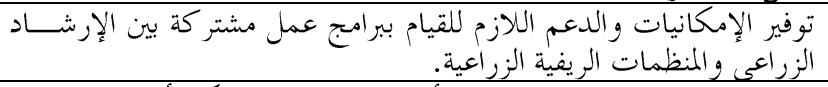 & 7 \\
\hline 9 & $T r, 1$ & $\varepsilon 1$ & r & 70,1 & 99 & 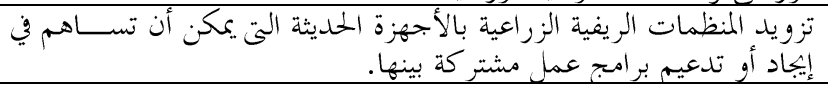 & v \\
\hline$\varepsilon$ & $\wedge \cdot, r$ & or & $\mathrm{v}$ & $0 ., \mathrm{V}$ & VV & 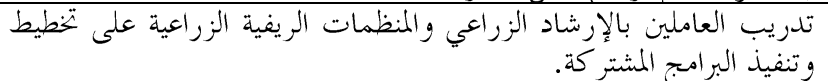 & $\wedge$ \\
\hline r & $\wedge 1, \wedge$ & $0 \leqslant$ & r & $7 \varepsilon, 0$ & 91 & 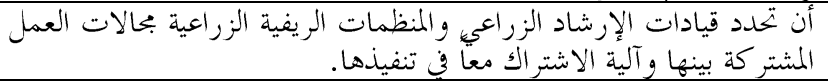 & 9 \\
\hline$\wedge$ & $70, Y$ & $\varepsilon r$ & $\wedge$ & $\sum 9, r$ & vo & 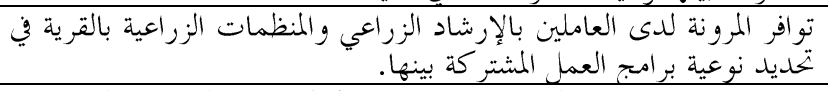 & 1 . \\
\hline 11 & 1 & $\mathrm{~V}$ & 11 & 9,9 & 10 & 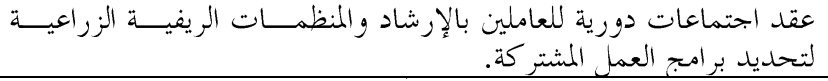 & 11 \\
\hline Ir & $r$ & r & Ir & $0, r$ & $\Lambda$ & تشجيع المنظمات الريغية للإشتر اك معا في برامج مختلفة كل فيما يخصه. & Ir \\
\hline
\end{tabular}

\section{التوصيـات}

1- العمل على تنمية وعى المسئولين و العاملين بمختلف المنظمــات

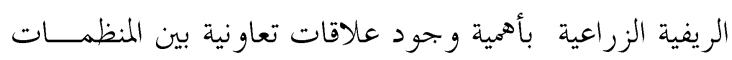

المختلفة.

r- وضع قواعد وإجراءات تنظيمية تكفل وجود علاقات تعاونية

$$
\text { فعالة بين مختلف المنظمات الريفية الزراعية. }
$$

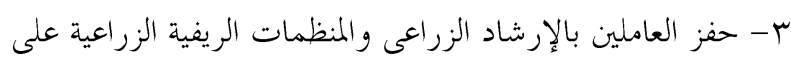

تفعيل العلاقات التعاونية بينهم.

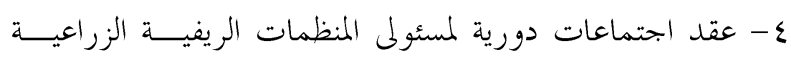

للتنسيق فيما بينهم.

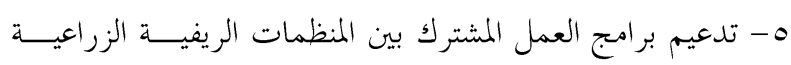

المختلفة.

ب- العمل على تذليل كافة المعوقات والمشكلات التي تحد من قيام

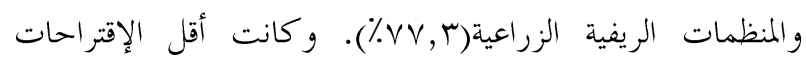

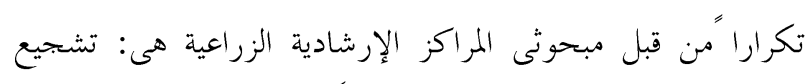

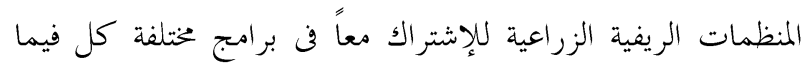

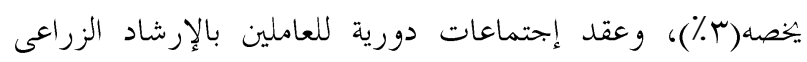
والمنظمات الريفية الزراعية لتحديد برامج العمل المشتركة بينها

وبالنظرلمقترحات المبحوثين عينتى البحث فيما يتعلق بزيادة

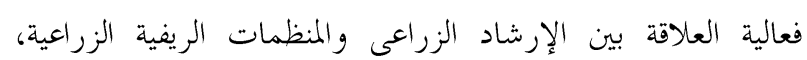

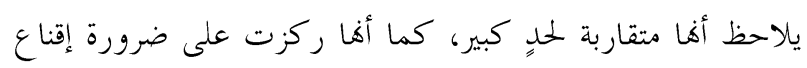
المسئولين والعاملين بالمنظمات الريفية الزراعية بما فيها الإرشاد

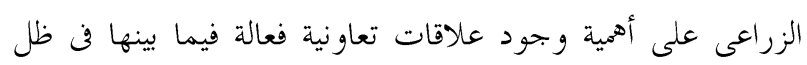
قواعد محددة وقنوات إتصال فعالة لتقوية وتدعيم العلاقات التعاونية بين المنظمات الزراعية المختلفة مع حفز وتشجيع تلك المنظمات على تفعيل العلاقات التعاونية فيما بينها بصفة مستمرة. 
المؤتمر الدولى السابع عشر للإحصاء وعلوم الحاســبـ وتطبيقاتــهـ

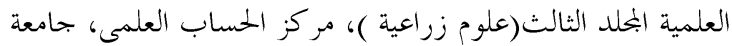

$$
\text { عين شمس إr-r أبريل. }
$$

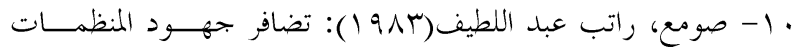

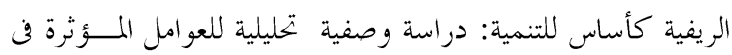

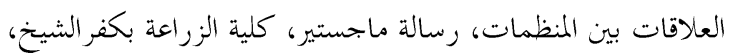
جامعة طنطا.

1ا- عبد اللا، مختار محمد، وراتب عبد اللطيف صومع(990): نحسـو

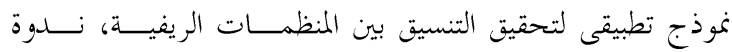

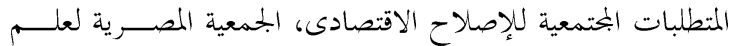
الإجتماع الريفى ومؤسسة فريدريش ناومان، القاهرة.

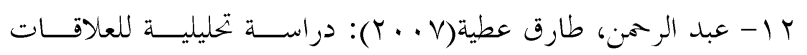

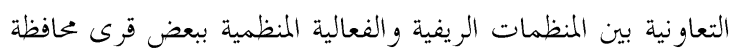

$$
\text { كفر الشيخ، رسالة دكتوراة، كلية الزراعة، جامعة كفر الشيخ. }
$$

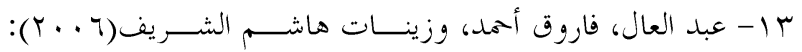

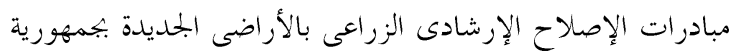

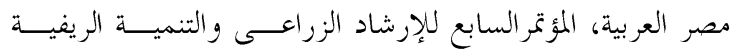

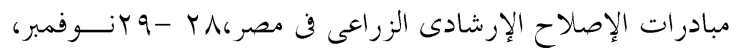

$$
\text { كلية الزراعة، جامعة المنصورة. }
$$

ع ا- كشك، محمد بهجت جاد الله(1991) (المنظمات وأسس إدارتا،

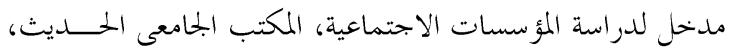

$$
\text { الأسكندرية. - مانحل }
$$

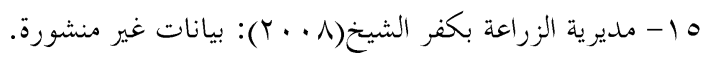

16-Krejcie, R.V.and Morgan, D.W, (1970): Determining Sample Size for Research Activities Educational Psychological Measurement, College Station, Durham, North Carolina.

17-Mulford, Charles .L,(1984): Interorganizational Relations: Implications for Community Development ,Human Service Press New York .

18-Oliver, Christin, (1990): Determinations of Interorganizational Relationships: Integration and Future Directions, Academy of Management Review, Vol.15, pp241-265.

19-Van De Ven, Andrew .H, (1976): On the Nature, Formation, and Maintenance of Relations among Organizations, the Academy of Management Review, Vol.1, No .4 pp24-36.
علاقات تعاونية فعالة بين الإرشاد الزراعى و المنظمات الريفيــة

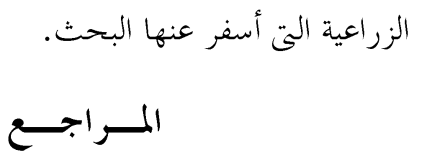

1- أبوحطب، رضا عبد الخالق (1991 1): مداخل الخددهـة الإرشـادية

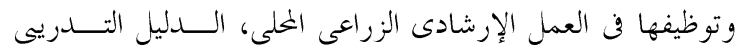

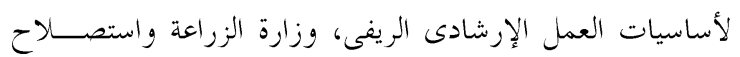

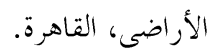

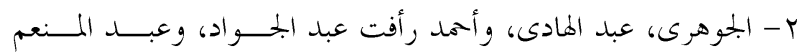
بدر(7 (1) ): دراسات في التنمية الإجتماعية- مدخل إســلامى، مكتبة هضة الشرق، القاهرة.

ب- السيد، مصطفى كامل محمد( (... ب): العلاقــات التفاعليــة بــين

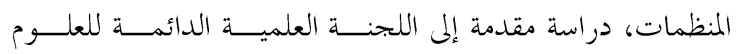
الاجتماعية الزراعية لترقية الأساتذة والأساتذة المساعدين.

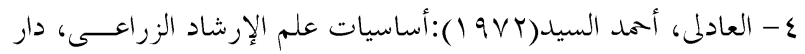
المطبوعات الجحديدة ، الأسكندرية.

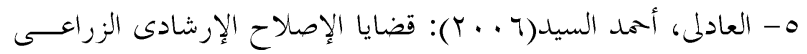

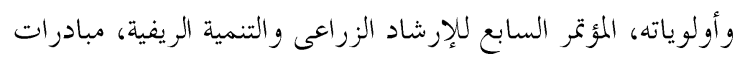

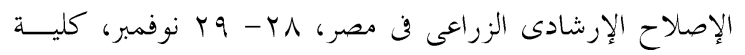

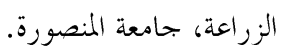

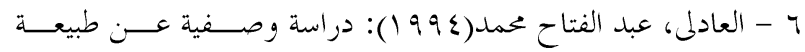

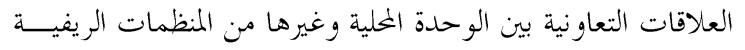

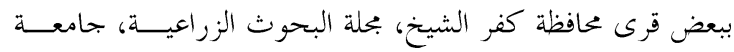

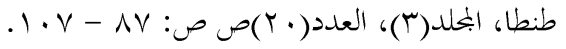
V- زهران، ييى على(994) (1997) الخدمات الاستشــارية الزراعيــة بــين

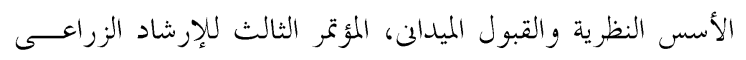

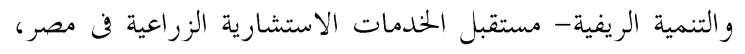
كلية الزراعة، جامعة المنصورة.

1- سلام، محمد شفيع(1990): دور الإرشــاد الزراعسى في التنميسـة

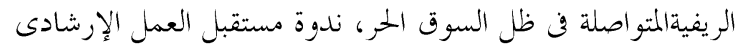

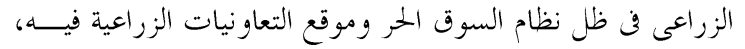

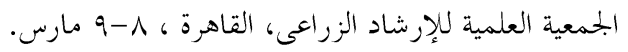

9- صومع، راتب عبد اللطيف(1999) (19): معوقات ومحددات التعاون بين

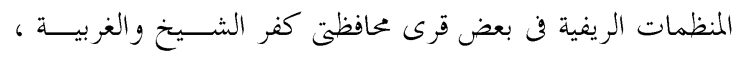




\title{
ABSTRACT \\ The Relationship between Agricultural Extension and Agricultural Rural Organizations As Seen by Agricultural Extension Workers in Kafrelsheikh Governorate
}

\author{
Hussein Ali Hagras, Allam Mohammed Tantawi
}

The main objective of this research was to identify the relationships between agricultural extension and agricultural rural organizations as seen by agricultural extension workers in Kafr Elsheikh governorate. The agricultural rural organizations were: Agricultural Cooperative Association, veterinary unit, and the village's Bank.

Data were collected by a personal questionnaire from two random samples consisting of 152 agents at the village's level, and 66 from the extension workers at the the extension Centers level in Kafr Elsheikh governorate Sample Size was decided according to Krejcie and Morgan tables. Percentages, frequencies, and the arithmetic means were used for analysis data.

The most important research findings are:

1- More than one third of all respondents mentioned weakness of the relationship between the agricultural extension and the rural agricultural organizations be week. The Two groups of Sample mentioned that the strong relationship has been absent Approximately.

2- Agricultural Cooperative Associations occupied the forefront of strength of the relationship between the agricultural extension and the studied rural agricultural organizations from point of view of all respondents, followed by village banks and veterinary units .The order was slightly different for in the other village level and extension centers level respondents.

3- The official form is the prevailing form in most dimensions of relationship of agricultural extension and studied agricultural rural organizations.
4- The major constraints that limit the effectiveness of the relationship between agricultural extension and the studied agricultural rural organizations were: lake of coordination \& the cooperation between the agricultural extension and rural agricultural organizations, complexity of the procedures needed for exchange information\& resources between agricultural extension and rural agricultural organizations, nonexislack of effective channels of communication between agricultural extension and rural agricultural organizations, and the weakness of the available possibilities for the agricultural extension and agricultural rural organizations, in general.

5- The major suggestions of the respondents to increase the effectiveness of relationship between agricultural extension and rural organizations were: simplifying procedures for the exchange of information, and resources and between agricultural extension and agricultural rural organizations, informing the officials and the workers in the organizations with the importance of cooperative relationship with the agricultural extension; encouraging the workers in the agricultural organizations and agricultural extension to consolidate cooperative relationships among themselves, supporting programs among villages level organizations, and to take enough measures to support cooperative relationship between agricultural extension and agriculture rural organizations. 